\title{
The Relation of the Plankton to some Chemical and Physical Factors in the Clyde Sea Area.
}

By

S. M. Marshall, B.Sc., Assistant Naturalist, And

A. P. Orr, M.A., B.Sc., A.I.C., Chemist.

From the Marine Station, Millport.

With 9 Figures in the Text and 10 Plates.

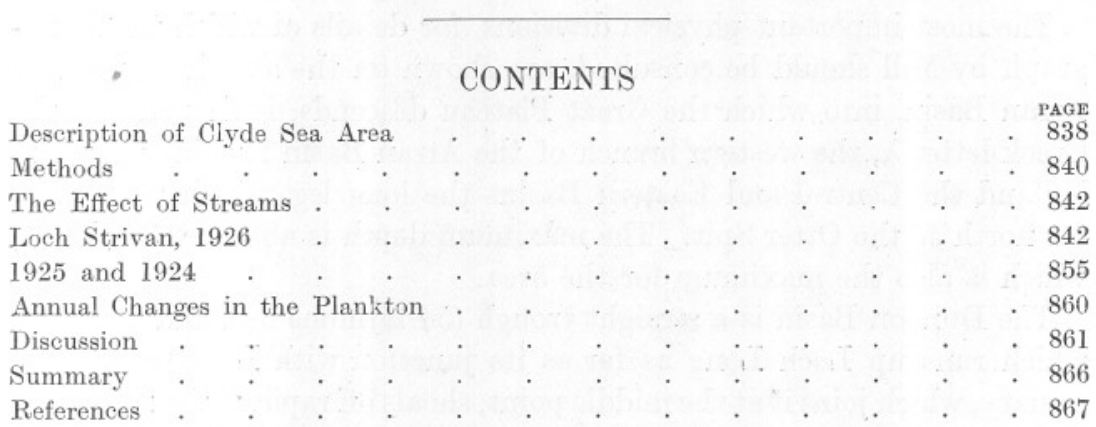

THE changes in the plankton and their relationship to the chemical and physical factors has long been a subject of inquiry, and an impetus has recently been given to this work by the development of more accurate methods of estimation of some of the factors by various workers on both the biological and chemical sides (Lohmann (18), McClendon (19), Atkins $(\mathbf{1}, \mathbf{2}, \mathbf{3}, \mathbf{4}, \mathbf{5})$, etc.). Only in isolated cases, however, has more than a general relationship been made out, and this work was undertaken with the object of correlating as closely as possible the changes in the plankton with the changes in some of the chemical and physical factors.

Plant and animal life is abundant in the Clyde Sea Area, and it was thought that the changes occurring would be more marked and so more easily studied than in the open sea. In 1924 a series of three cruises was made round the whole area, and in 1925 this number was increased to five and further chemical estimations were made. In 1926 it was felt that more frequent observations would lead to more valuable results, and Loch Strivan was visited weekly for the greater part of the year. 


\section{Description of Clyde Sea Area.}

The area has been described in detail by Mill (20), and a summary of his description is given below ( Text Fig. 1).

The Kintyre peninsula, which forms the western boundary of the area, is separated from Ireland by the North Channel, eleven miles across. The southern boundary of the area stretches from the Mull of Kintyre to Galloway, a distance of twenty-three miles. On the south it is divided from the Irish Sea by the Great Plateau, which has an average depth of 24 fathoms, this deepening northward to the Arran Basin. The islands of Arran, Inchmarnock, Bute, and the Cumbraes divide this into a number of narrow sounds, continued to the north as a series of lochs or fjords. The north-west is prolonged into Loch Fyne, which curves off to the north-east, and the north-east into Loch Long. This is joined on the east by the shallow estuary of the Clyde, the only important river entering the area.

The most important physical divisions, for details of which the monograph by Mill should be consulted, are shown on the sketch map. The Arran Basin, into which the Great Plateau descends, is shaped like the Greek letter $\lambda$, the western branch of the Arran Basin forming the short leg and the Central and Eastern Basins the long leg, which reaches as far north as the Otter Spit. The maximum depth is about 107 fathoms, which is also the maximum for the area.

The Dunoon Basin is a straight trough (54 fathoms maximum depth), which runs up Loch Long as far as its junction with Loch Goil. The estuary, which joins it at the middle point, shoals off rapidly, the navigable channel being maintained by dredging. On the north the estuary is joined by the Gareloch, which has a maximum depth of 21 fathoms. Loch Long is a continuation to the north of the Dunoon Basin with a maximum depth of 35 fathoms, and Loch Goil, with a maximum depth of 47 fathoms, joins it on the west.

Loch Strivan, which runs almost due north and south, has a maximum depth of 42 fathoms; the Kyles of Bute and Loch Ridun are shallower, the maximum depth being 23 fathoms. Loch Fyne is divided into two basins, the Gortans Basin and the Upper Loch Fyne Basin, the former with a maximum depth of 36 fathoms and the latter with a maximum depth of 80 fathoms.

The different lochs are separated from the more open water by " thresholds " or bars, these being more marked in some lochs than in others. Loch Strivan is an apparent exception, unless the shallow plateau between it and the Dunoon Basin be counted as such.

As regards the effect of the river, Mill says: "The Clyde Sea Area has no more intimate physical relation with the river after which it is 

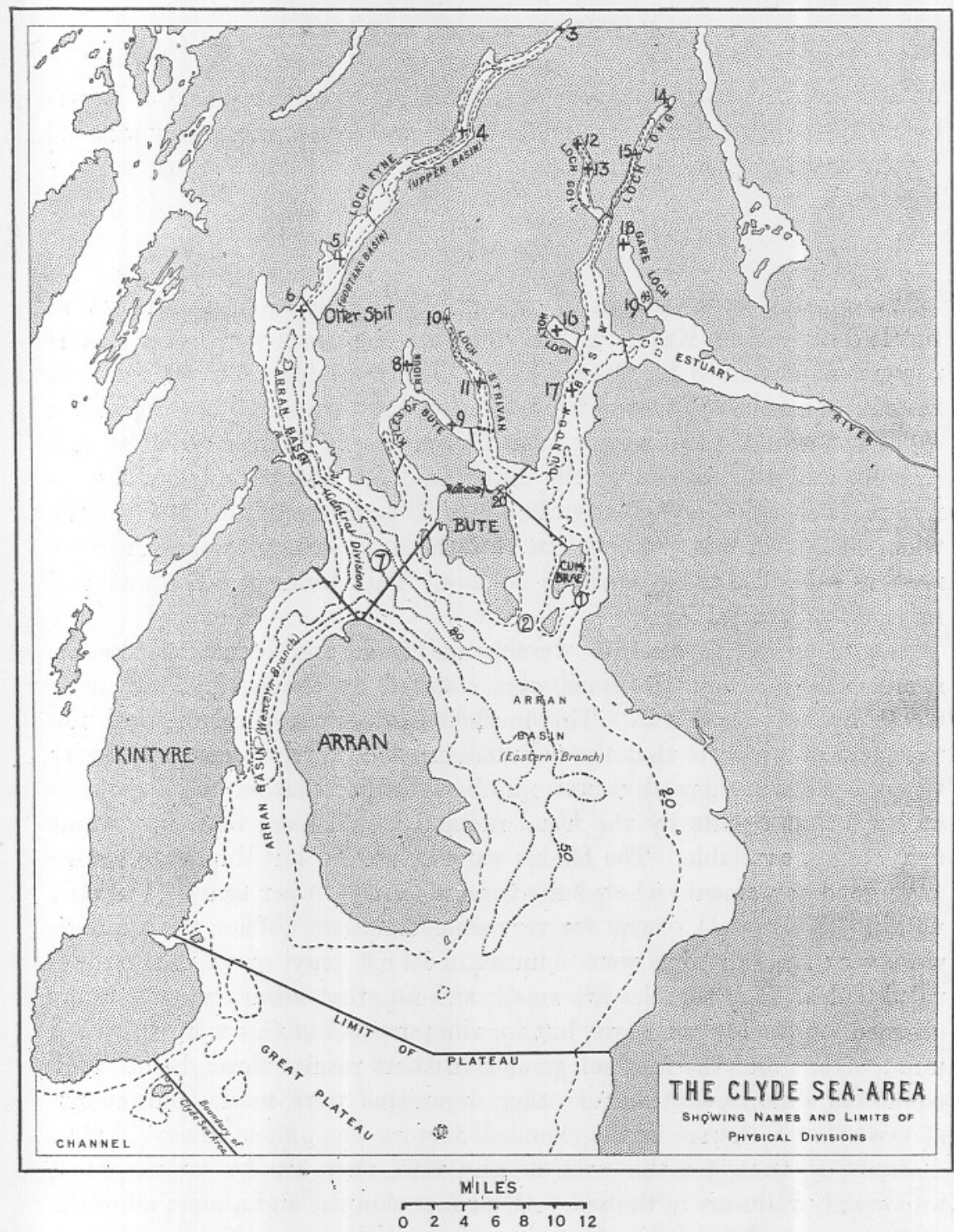

FIG. 1.-Depth contours are shown for - - - $20 \mathrm{fm} ., \ldots . .50 \mathrm{fm} ., \ldots \ldots 80 \mathrm{fm}$. Stations worked are shown by crosses and numbers.

\section{Depth}

in $\mathrm{fm}$.

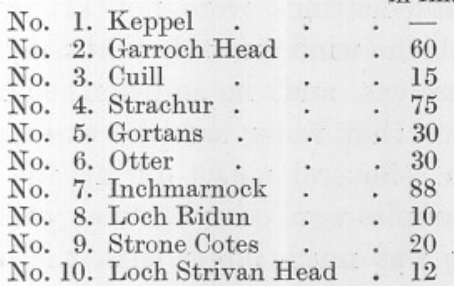

Depth in $\mathrm{fm}$.

No. 11. Clapochlar. . $\quad .40$ No. 12. Loch Goil Head . $\quad 27$

No. 13. Stuckbeg . . . 40

No. 14. Arrochar . . . 10

No. 15. Thornbank . . 35

No. 16. Holy Loch . . . 10

No. 17. Gantock . . . $\quad 55$

No. 18. Gareloch Head . . 10

No. 19. Clynder . . . 23

No. 20. Meteorological Station. 
named than the North Sea has with the Thames or the Rhine." In the lochs, on the other hand, the surface layers are often considerably affected by the drainage from the hills.

\section{Methods.}

Water samples were taken at various depths with the insulating waterbottle described by Knudsen (16). The tow-nets used were $(a)$ a closing tow-net as described by Ostenfeld and Jespersen (25), but with canvas instead of open mesh in the top part of the net (mesh 200 to the inch) ; (b) open tow-nets (diameter of mouth 18 inches) of 30 meshes to the inch (coarse) and 120 meshes to the inch (fine). A coarse and a fine townetting were always taken within 1 or 2 fathoms of the surface and, when the depth was greater than 15 fathoms, a coarse and a fine townetting were also taken near the bottom. The closing tow-net was used mainly for vertical hauls.

The water-bottle samples were centrifuged, and counts in 20 c.c. samples were made. Diatoms were counted by chains, and not, as is usual, by individual cells. This method has certain disadvantages, not the least of which is that the results cannot be directly compared with those from elsewhere, but the numbers during diatom maxima were so large that counts by the usual method would have been impossible in the time available. The chains vary in length, but duplicate counts gave good agreements (the results were within \pm 10 per cent and usually within \pm 5 per cent), except for very small numbers. When the numbers were very large diatoms were counted in 10 c.c. only, or on part only of ruled slides. The samples are small, and no great accuracy is therefore claimed for the low numbers, but for the purposes of this work these are unimportant and the method gives consistent results throughout. Full counts of dinoflagellates and other organisms were made, but events showed that a change in the chemical factors was almost always due to diatoms, so that, for this area at any rate, they are by far the most important producers in the sea. All surface samples and almost all of the others were counted while fresh in order to see the small naked forms, but a few from the deeper layers in 1924 and 1925 and two from Loch Strivan in 1926 were preserved in formalin.

Quantitative estimations of the tow-nettings were not attempted. The speed of drift varied so much with the wind and tide that they were not always comparable among themselves, and, in addition, so much passes through the meshes of the nets that water samples are a more reliable guide for the microplankton. Several times during the year results from tow-nettings and water samples were completely at variance, because, of two diatoms present, one was much larger than the other, 
and so, though really unimportant, was retained in much greater numbers in the tow-net than the other smaller form.

In the curves which follow, diatom numbers are drawn on the logarithmic scale. This is necessary because of the enormous variation, but it leads to an inevitable difficulty in reading them. The numbers quoted in the text always refer to the number of diatom chains (or other organisms) present in a 20 -c.c. water sample.

The water samples were transferred at once to oxygen bottles and Winchesters, the temperature being taken by a standard thermometer and read to $\cdot 01^{\circ} \mathrm{C}$.

Salinity was determined by titration of the chloride and dissolved oxygen by Winkler's titration method.

The $\mathrm{pH}$ value was read by McClendon's (19) method, the three indicators, phenol red, cresol red, and thymol blue, being used and values read to $.01 \mathrm{pH}$. The comparison tubes were renewed on several occasions, either because a fresh dilution of the dye proved necessary or because one or more of the tubes showed a change. In the early cruises 30 c.c. tubes were used, but from 192510 c.c. tubes were used, as it was found as easy to read these. Corrections were not made for the change in salinity in the upper layers, since dilution was due to the addition of water whose $\mathrm{pH}$ value and buffer effects were not known. The results will thus be liable to error in cases when the salinity change is marked, but, as will be seen, this effect is very small compared to the other changes encountered.

Phosphates were estimated by Atkins' modification of the Denigès method (4) in 1925 and 1926, and silicates by his modification of Diénert and Wandenbulcke's method in $1926(\mathbf{2}, \mathbf{5})$.

Nitrates were determined by Harvey's (10) method in 1926 and nitrites by Orr's (23) modification of Buch's method.

During the early part of the work estimations of the organic matter by Lenormand's $\left(\mathbf{1}^{\mathbf{y}}\right)$ method were made. This was given up for two reasons : (a) there was an unknown amount of organic material, including diatoms, in suspension; $(b)$ the tint of the test solution was not the same as that of the standard, a difficulty which has since been overcome. The results obtained proved of little value in relating the different factors.

The curves for oxygen saturation were obtained from Fox's (') table crd those of $\mathrm{S}_{t}$ by Knudsen's (15) tzbles.

The meteorological data were obtained from Mr. Davidson through the courtesy of Sir John Reid, to both of whom our thanks are due. The meteorological station (see Fig. 1) is situated on Bute to the south of Loch Strivan. The daily records of hours of sunshine were kindly given by the Rothesay Town Council.

Wind force is given on the Beaufort scale, and the graph (Plate I, 
Fig. 2) has been formed by taking the N. and S, components of the wind each day. As the loch lies almost due north and south these are the important directions. This, however, is only an approximation, as winds which vary a little from these directions tend to draw up or down the loch. With easterly or westerly winds there are variable gusts in the loch, but no steady wind.

\section{The Effect of Streams.}

Since inshore waters are richer in plankton than the open sea it is to be expected that the inflow from streams is at least partly the cause of this. It was necessary for this reason to examine the streams in the area. A general division can be made into the polluted and unpolluted streams. The polluted streams are those which have a town or village on their banks, and include the Clyde itself and the larger streams in Ayrshire. The unpolluted streams are those at the heads of lochs. The former are rich in dissolved phosphate and silicate, and certainly contain important quantities of dissolved nitrogen compounds, though no analyses of these were made. The rivers in the lochs, on the other hand, are rich in dissolved silicates (averaging about $4 \mathrm{mg}$. per litre), though the value varies considerably, and poor in dissolved phosphate (varying from zero to $20 \mathrm{mg}$. per cubic metre). There are a few exceptions to this in the lochs, but in all cases when phosphate is higher than this there is evidence of pollution. The small quantity of phosphate in the streams at Loch Strivan head is shown clearly by Plate VIII, Fig. 14, where phosphate values are low on three occasions (June 21st, August 19th, October 4th), when diatoms (Plate VIII, Fig. 15) are low in numbers and salinity (Plate VI, Fig. 10) exceptionally low.

Several analyses of the nitrates in the streams were made, and in all cases high results were obtained, but this is probably due in part to the presence of ferric iron in solution. The slopes of the lochs consist of mica schists and contain considerable quantities of magnetite, from which iron may possibly be derived. The variation in silicate results from the rapid change in the volume of the streams after a shower of rain. The slopes of the lochs are generally very steep, especially in Loch Strivan, and rain-water drains off rapidly. Organic matter in the streams was high compared with the sea. In polluted streams it was very high, and in the unpolluted streams varied from 4 to $6 \mathrm{mg}$. per litre.

\section{Loch Strivan, 1926.}

The work on Loch Strivan was carried out in greater detail than that on the rest of the area, and the results obtained proved useful for the understanding of conditions found in previous years. It will therefore 
be convenient to take it first. The loch, which was visited weekly from the end of January till the end of November, was chosen for the work because of its peculiar advantages. It is close to the Marine Station and can be reached in 2-3 hours, its sheltered position makes it possible to work there in any weather and a good harbour lies near. It is the only loch with no village on its shores, and so there is no risk of contamination. The ratio of water-surface : land-drainage area : total area is $1: 3 \cdot 11: 4 \cdot 11$. This means that rainfall has less effect than in any other loch except the Gareloch, which is unsuitable, because it is affected by the River Clyde. Two small streams enter at the head, while during rain innumerable burns form on the steep slopes. The total area of the loch is five square miles (Text Fig. 1, north of dotted line). Two stations were worked, one at the head of the loch in the narrow part, and one off Clapochlar Point (see Text Fig. 1). The positions varied somewhat due to drifting of the boat; the depths worked in were about 14 fathoms as Loch Strivan head, and abou 30 fathoms at Clapochlar. At both stations the bottom sample was taken at 1 fathom above the bottom.

The changes during the year followed much the same course at both stations ; but Loch Strivan head, on account of its position and depth, is subject to greater fluctuations in salinity and is more easily affected by mixing due to wind. Clapochlar is more stable and more reliable, and the descriptions which follow refer to it, although they are generally true for Loch Strivan head also.

Horizontal curves showing the course of events throughout the year have been drawn for total diatoms (Plate I, Fig. 1; Plate IX, Fig. 16), diatom species at the surface (Plate II, Fig. 3), wind (Plate I, Fig. 2), air temperature (Plate X, Fig. 18), sea temperature (Plate V, Fig. 9 ; Plate VI, Fig. 11), salinity (Plate VI, Fig. 10 ; Plate X, Fig. 19), $\mathrm{S}_{\mathrm{t}}$ (Plate VII, Fig. 12), pH value (Plate II, Fig. 4), dissolved oxygen saturation (Plate III, Fig. 5 ; Plate VII, Fig. 13), and phosphate (Plate III, Fig. 6 ; Plate VIII, Fig. 14). Plates I-V should be consulted in reading the following descriptions :-

January 29th-March 17th. Up till March 17th vertical mixing was going on in the loch, the temperature falling from bottom to surface. There were considerable fluctuations in the salinity of the surface layer, which was generally low, while the deeper layers did not vary much. The $\mathrm{pH}$ value also was lowest at the surface, while the values in the deeper layers were much the same and kept at about $\mathrm{pH} 8 \cdot 00$. The dissolved oxygen saturation values generally rose towards the surface, which is not to be expected since vertical mixing was still going on. There were irregularities in the curves, the values at some depths being unexpectedly low. The cause is uncertain, but it is suggestive that herring were unusually abundant and were being fished in the loch. Phosphate values 
varied between 40 and $50 \mathrm{mg}$. per cubic metre. During this time diatoms were very scarce.

March 23rd. The diatoms were not counted on March 17th, but on the 23rd (Plate IV, Fig. 7, and Table I) there were already 8,000 at the surface and 450 at 5 fathoms. Probably they had been present at the surface only, the week before. These samples contained almost nothing but Skeletonema costatum, which was the predominant species during the spring maximum. Other diatom species were present, but were negligible in numbers. The temperature still fell to the surface, but the surface layer was slightly supersaturated with oxygen, and the $\mathrm{pH}$ value had risen and the phosphate fallen a little. The other layers were unaffected.

TABle I. March 23rd.

\begin{tabular}{|c|c|c|c|c|c|c|}
\hline $\begin{array}{l}\text { Depth in } \\
\text { fm. } \\
0\end{array}$ & $\begin{array}{c}\text { Tempera- } \\
\text { ture in }{ }^{\circ} \mathrm{C} \text {. } \\
6.66\end{array}$ & $\begin{array}{c}\text { Salinity. } \\
\% \\
28.83\end{array}$ & $\begin{array}{c}\mathrm{pH} \text { value. } \\
8.05\end{array}$ & $\begin{array}{c}\% \text { saturation } \\
\text { of } \mathrm{O}_{2} . \\
106.5\end{array}$ & $\begin{array}{l}\text { Phosphate } \\
\text { mg. per c/m. } \\
38\end{array}$ & $\begin{array}{c}\text { Diatom } \\
\text { chains in } \\
20 \text { c.c. } \\
8,020\end{array}$ \\
\hline 5 & $7 \cdot 09$ & $32 \cdot 05$ & $8 \cdot 03$ & $95 \cdot 7$ & 47 & 448 \\
\hline 10 & $7 \cdot 00$ & $33 \cdot 50$ & 8.00 & $91 \cdot 5$ & 46 & 34 \\
\hline 20 & $7 \cdot 07$ & $34 \cdot 08$ & $7 \cdot 99$ & $84 \cdot 0$ & 46 & - \\
\hline 33 & $7 \cdot 06$ & 33.98 & $7 \cdot 99$ & $82 \cdot 8$ & 46 & - \\
\hline
\end{tabular}

On April 2nd (Plate IV, Fig. 7, and Table II) the diatoms were still richest at the surface $(24,000)$, but they were also rich at 5 and 10 fathoms. The loch was homothermic and mixed from top to bottom, and there was a general rise in $\mathrm{pH}$ and oxygen values from top to bottom (the 5 -fathom layer was slightly supersaturated with oxygen), and a fall in phosphate in all layers. Mixing had evidently distributed the photosynthetic changes throughout the water.

\section{TABLE II. April 2nd.}

\begin{tabular}{|c|c|c|c|c|c|c|}
\hline $\begin{array}{l}\text { Depth in } \\
\text { fm. } \\
0\end{array}$ & $\begin{array}{c}\text { Tempera- } \\
\text { ture in }{ }^{\circ} \mathrm{C} \text {. } \\
6.98\end{array}$ & $\begin{array}{c}\text { Salinity. } \\
\% \text { \% } \\
33 \cdot 42\end{array}$ & $\begin{array}{c}\mathrm{pH} \text { value. } \\
8.06\end{array}$ & $\begin{array}{c}\% \text { saturation } \\
\text { of } \mathrm{O}_{2} . \\
97 \cdot 3\end{array}$ & $\begin{array}{l}\text { Phosphate } \\
\mathrm{mg} \text {. per c/m. } \\
32\end{array}$ & $\begin{array}{l}\text { Diatom } \\
\text { chains in } \\
20 \text { c.c. } \\
24,200\end{array}$ \\
\hline 5 & 6.94 & 33.51 & 8.05 & $103 \cdot 1$ & 32 & 14,920 \\
\hline 10 & $6 \cdot 97$ & $33 \cdot 70$ & $8 \cdot 04$ & $94 \cdot 2$ & 35 & 11,600 \\
\hline 20 & $7 \cdot 00$ & $34 \cdot 46$ & $8 \cdot 04$ & $93 \cdot 7$ & 41 & 78 \\
\hline 33 & $7 \cdot 10$ & $34 \cdot 63$ & $8 \cdot 03$ & $92 \cdot 5$ & 39 & - \\
\hline
\end{tabular}

On A prit 7th (Plate IV, Fig. 7, and Table III) diatoms had reached their maximum for the year $(33,000)$ at 5 fathoms, while the surface numbers had fallen off considerably, and the 10 -fathom numbers were still increasing. A sudden rise in air temperature caused a rise in the temperature of the surface layer. The temperature there was now higher than 
that of the deeper layers, and remained so till the autumn. This rise stopped vertical mixing due to temperature, and was followed by a differentiation of the loch. The $\mathrm{pH}$ value showed a sharp rise at the surface and a slight one at 5 fathoms. The surface layer was highly supersaturated with oxygen (139 per cent), and the 5-fathom layer slightly so. The phosphate at the surface showed an abrupt fall to its minimum value for this increase ( $12 \mathrm{mg}$. per cubic metre) and a smaller fall at 5 fathoms.

TABLE III. April 7th.

\begin{tabular}{|c|c|c|c|c|c|c|}
\hline $\begin{array}{l}\text { Eepth in } \\
\text { fm. } \\
0\end{array}$ & $\begin{array}{c}\text { Tempera- } \\
\text { ture in }{ }^{\circ} \mathrm{C} \text {. } \\
8.68\end{array}$ & $\begin{array}{c}\text { Salinity. } \\
\% \\
32 \cdot 06\end{array}$ & $\begin{array}{c}\mathrm{pH} \text { value. } \\
8.36\end{array}$ & $\begin{array}{c}\% \text { saturation } \\
\text { of } \mathrm{O}_{2} \text {. } \\
138 \cdot 6\end{array}$ & $\begin{array}{l}\text { Phosphate } \\
\text { mg. per c/m. } \\
12\end{array}$ & $\begin{array}{c}\text { Diatom } \\
\text { chains in } \\
20 \text { e.c. } \\
10,200\end{array}$ \\
\hline 5 & $7 \cdot 10$ & $33 \cdot 57$ & $8 \cdot 07$ & $104 \cdot 2$ & 25 & 33,000 \\
\hline 10 & $6 \cdot 94$ & $33 \cdot 76$ & $8 \cdot 04$ & $97 \cdot 5$ & 47 & 13,500 \\
\hline 20 & $7 \cdot 02$ & $34 \cdot 65$ & $8 \cdot 02$ & $91 \cdot 4$ & 50 & 903 \\
\hline 30 & $7 \cdot 12$ & $34 \cdot 97$ & $8 \cdot 03$ & $93 \cdot 2$ & 41 & 131 \\
\hline
\end{tabular}

On A prit 13th (Plate IV, Fig. 7, and Table IV) the diatoms had decreased at both surface and 5 fathoms, while the 10 -fathom layer had reached its maximum $(15,000)$. Diatoms were rich also to the bottom of the loch. The temperature had risen slightly; the $\mathrm{pH}$ value at the surface had reached its maximum for the spring increase ( $\mathrm{pH} 8 \cdot 38$ ), and had risen considerably at 5 fathoms, and slightly at 10 fathoms and 20 fathoms. The dissolved oxygen saturation had fallen a little at the surface, but had risen to its maximum for 5 fathoms (117 per cent). The phosphate remained steady at the surface, showed a further fall at 5 fathoms and a pronounced fall at 10 fathoms.

TABLE IV. April 13th.

$\begin{array}{ccccccr}\begin{array}{c}\text { Depth in } \\ \text { fm. }\end{array} & \begin{array}{c}\text { Tempera- } \\ \text { ture in }{ }^{\circ} \mathrm{C} .\end{array} & \begin{array}{c}\text { Salinity. } \\ \%\end{array} & \begin{array}{c}\text { pH value. } \\ \%\end{array} & \begin{array}{c}\text { saturation } \\ \text { of } \mathrm{O}_{2} \cdot\end{array} & \begin{array}{c}\text { Phosphate } \\ \text { mg. per c/m. }\end{array} & \begin{array}{c}\text { Diatom } \\ \text { chains in } \\ 20 \text { c.c. }\end{array} \\ 5 & 8 \cdot 32 & 32 \cdot 38 & 8 \cdot 38 & 135 \cdot 0 & 15 & 2,036 \\ 10 & 7 \cdot 53 & 33 \cdot 55 & 8 \cdot 22 & 116 \cdot 5 & 17 & 3,617 \\ 20 & 7 \cdot 00 & 33 \cdot 89 & 8 \cdot 09 & 95 \cdot 5 & 31 & 15,000 \\ 33 & 7 \cdot 05 & 34 \cdot 53 & 8 \cdot 08 & 90 \cdot 6 & 40 & 9,210 \\ & 7 \cdot 09 & 34 \cdot 75 & 8 \cdot 05 & 89 \cdot 7 & 43 & 9,270\end{array}$

On April 20th (Plate IV, Fig. 7, and Table V) diatoms had almost disappeared, rising to a few hundreds only in the deeper layers. The $\mathrm{pH}$ value had fallen considerably at the surface and slightly at 5 fathoms while at 10 fathoms it had risen slightly. The dissolved oxygen saturation value showed a considerable fall at both surface and 5 fathoms. 
At 10 fathoms it had risen, and this layer was supersaturated (101 per cent) for the only time during the year. The 20 -fathom value showed a slight fall. The phosphate values remained much the same at the surface and 5 fathoms, below which the change was small.

\begin{tabular}{|c|c|c|c|c|c|c|}
\hline $\begin{array}{l}\text { Depth in } \\
\mathrm{fm} . \\
0\end{array}$ & $\begin{array}{c}\text { Tempera- } \\
\text { ture in }{ }^{\circ} \mathrm{C} \text {. } \\
7.63\end{array}$ & $\begin{array}{c}\text { Salinity. } \\
\% \circ \\
33 \cdot 43\end{array}$ & $\begin{array}{c}\mathrm{pH} \text { value. } \\
8 \cdot 20\end{array}$ & $\begin{array}{c}\% \text { saturation } \\
\text { of } \mathrm{O}_{2} . \\
105 \cdot 9\end{array}$ & $\begin{array}{l}\text { Phosphate } \\
\text { mg. per c/m. } \\
\text { I } 6\end{array}$ & 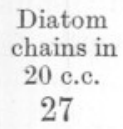 \\
\hline 5 & $7 \cdot 63$ & $33 \cdot 41$ & $8 \cdot 20$ & $105 \cdot 1$ & 19 & - \\
\hline 10 & $7 \cdot 32$ & $33 \cdot 69$ & $8 \cdot 14$ & $101 \cdot 2$ & 23 & 86 \\
\hline 20 & $7 \cdot 04$ & $34 \cdot 33$ & $8 \cdot 02$ & $86 \cdot 7$ & 37 & 274 \\
\hline 30 & $7 \cdot 09$ & $34 \cdot 59$ & $8 \cdot 02$ & $81 \cdot 3$ & 44 & 325 \\
\hline
\end{tabular}

This marks the end of the spring diatom increase. It is obvious that there is a close connection between the number of diatoms present and the changes in the sea-water. The diatoms begin to increase at the surface and spread downwards, the numbers decreasing in the surface layer when its phosphate content has fallen to a low value, and at 5 fathoms when this in turn has lost most of its phosphate. In the 10-fathom layer the changes are not so marked, and the phosphate is not used up to the same extent. Below this the diatoms are very rich, but only for a short time, and the changes are slight and irregular. The high numbers may be due to diatoms which are falling from the surface layers to the bottom, and are not photosynthesizing. Changes in $\mathrm{pH}$, oxygen, and phosphate values correspond to diatom numbers, but there is sometimes an apparent lag between the appearance of diatoms and the changes in any particular layer. It seems doubtful whether this really occurs, and probably if the loch were visited every day a better correlation would be found.

April 27th-May 18th. A small second wave of Skeletonema now appeared at the surface, and reached its maximum $(2,500)$ at 5 fathoms a week later. It had at the same time spread to the bottom. The following week, May 11th, a second and larger wave of Skeletonema appeared at surface and 5 fathoms, reaching a value of 9,000 . The high number at the 5 fathoms this week may be partly due to the remains of the first wave, but from the behaviour of Skeletonema as a rule this does not seem probable. During these waves the $\mathrm{pH}$ and dissolved oxygen saturation values followed the course of the diatoms exactly at the surface and at 5 fathoms. At 10 fathoms there was a corresponding rise in dissolved oxygen saturation, but not in $\mathrm{pH}$ value. The surface phosphate value remained low all this time, but there was, on 27th April, a steep rise in 
the value of the 5- and 10 -fathom layers, which was probably due to mixing with the deeper water. After this the values in these layers followed the course of the diatoms.

May 18th-June 4th. On May 18th the number of diatoms was almost the same from top to bottom, and a few hundred Chatoceros cinctum were present in the surface layers. The following week, however, Skeletonema numbers had fallen very low and about 1,000 Chætoceros were present at surface, 5 fathoms and 10 fathoms. On June 4th Chætoceros had its maximum of 2,500 , but was present only at the surface.

In spite of its small numbers Chætoceros had a remarkably large effect on $\mathrm{pH}$, dissolved oxygen saturation, and phosphate values at all three depths, the 10-fathom effect being delayed (cf. p. 846). The surface and 5 -fathom layers were completely denuded of phosphate on 25th May. On June 4th dissolved oxygen saturation and $\mathrm{pH}$ values were falling and phosphate was being regenerated at 5 fathoms, at which depth there were only a few diatoms.

During this period there was in the deeper layers a gradual fall in dissolved oxygen saturation and $\mathrm{pH}$ value, and a gradual rise in phosphate, which continued till the autumn turnover.

June 10 th-July 14 th. Diatoms were now very scarce until the 29 th June (Plate I, Fig. 1 ; Plate II, Fig. 3), when there was a sudden appearance of 3,000 at the surface. The following week this rich layer was found at 10 fathoms, while at the surface and at 5 fathoms diatoms were scarce, although presumably they had been numerous at 5 fathoms during the week. The diatoms were mixed, Cerataulina bergoni, Skeletonema costatum, and Chatoceros spp. forming the majority. On July 14th diatoms had disappeared again. While diatoms were few there was a fall in $\mathrm{pH}$ and dissolved oxygen saturation values, the latter actually falling below 100 per cent at the surface on June 22nd. Phosphate was being regenerated. With the appearance of the diatoms the $\mathrm{pH}$ and dissolved oxygen saturation values rose and phosphate fell at the surface, while the 5- and 10 -fathom layers were affected in succeeding weeks. The two weeks following the 29th June were marked at the surface by a further rise in $\mathrm{pH}$ and dissolved oxygen saturation value and a fall in phosphate, although there were no diatoms to account for it. The deep layers were unaffected, and were steadily becoming richer in phosphate and lower in $\mathrm{pH}$ value and oxygen saturation.

July 21st-September 28th. The end of July marks the beginning of another series of diatom increases which lasted till the middle of September. It began on July 21st (Text Fig. 2 and Table VI) with a few hundred Nitzschia seriata present in the surface and 5 -fathom layers. The following week (Text Fig. 3 and Table VII) the numbers at both depths had increased to thousands, and on August 3rd (Text Fig. 4 and Table VIII) 

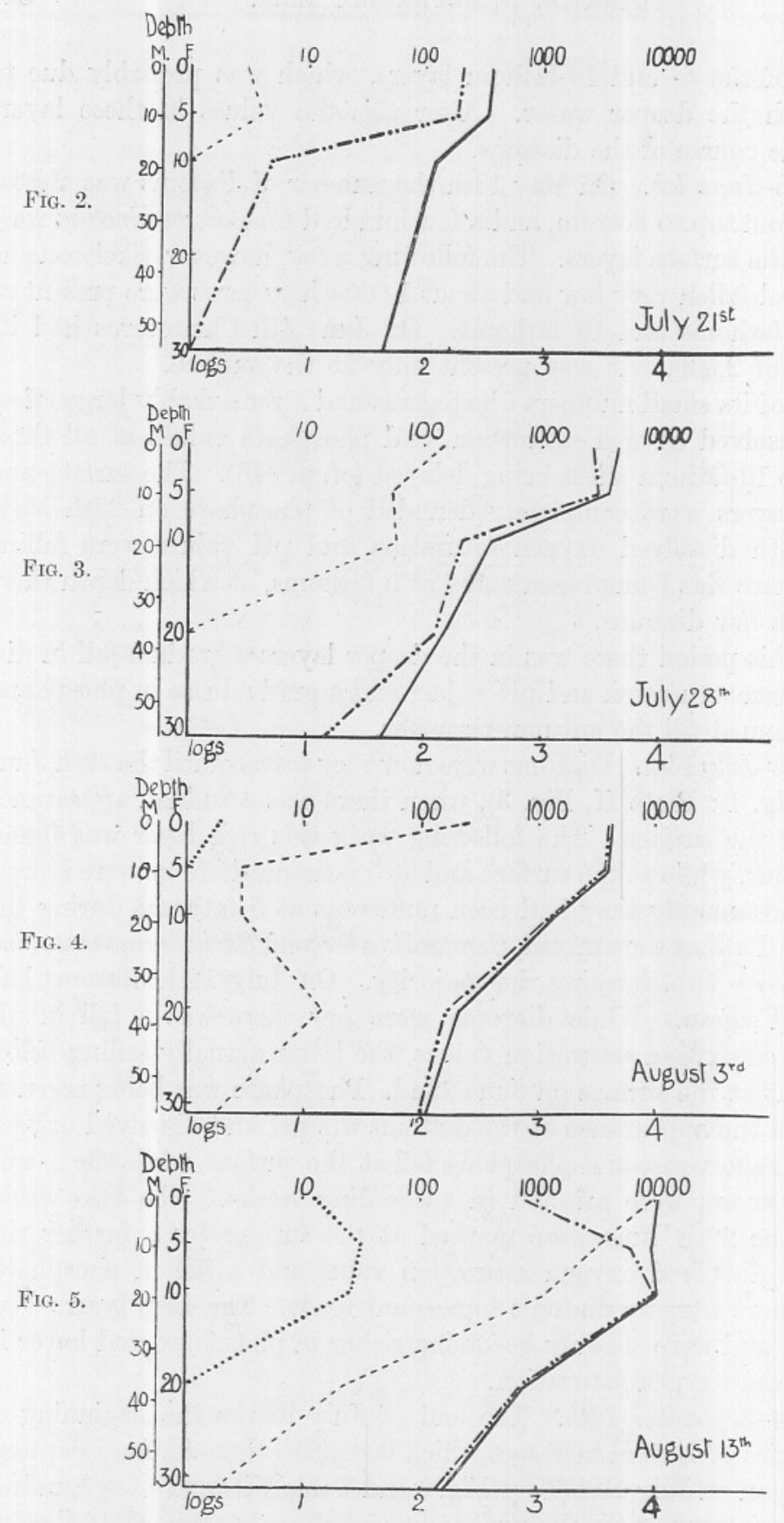

Figs. 2-5.-Clapochlar, 1926. Distribution of diatoms.

total diatoms. - .-... Nitzschia seriata, - - Leptocylindricus danicus, ...... Eucampia zoodiacus. 
there was a further small rise in both layers, while the numbers at 10 fathoms had increased to more than 1,000. This week there were also 300 Leptocylindricus danicus at the surface. On August 13th (Text Fig. 5, Table IX) both species of diatom had increased, and there were about

FIg. 6.

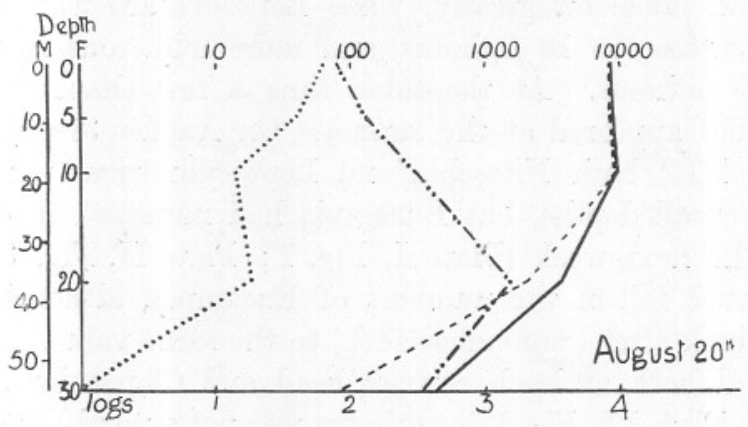

FIG. 7 .

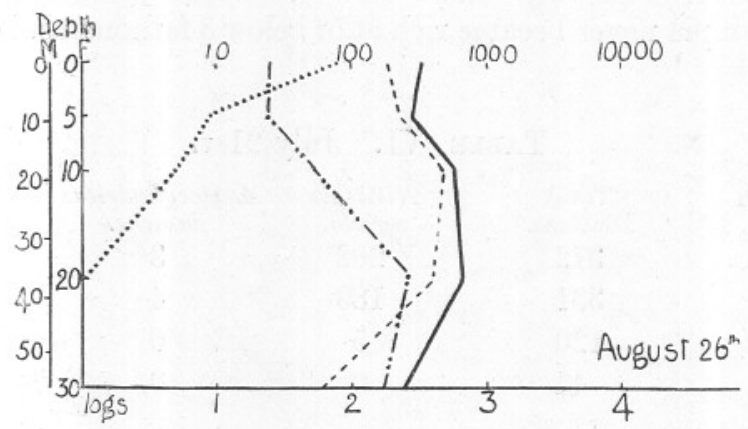

FIg. 8.

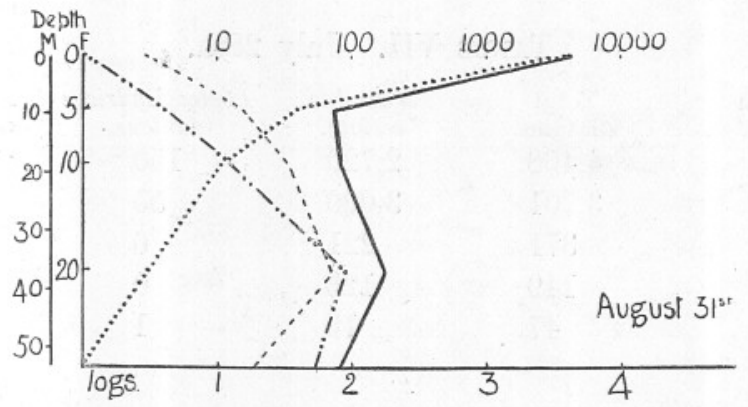

Figs. 6-8.-Clapochlar, 1926. Distribution of diatoms.

— total diatoms, _..... Nitzschia seriata, - - - Leptocylindricus danicus, ...... Eucampia zoodiacus.

10,000 present at the surface, 5 and 10 fathoms. The surface sample contained practically nothing but Leptocylindricus, the 5-fathom sample a mixture of Nitzschia and Leptocylindricus, and the 10 fathom and samples below mainly Nitzschia. Nitzschia had left the surface, and 
had begun to sink into the deeper layers, having its maximum at 10 fathoms, while Leptocylindricus was still richest at the surface. The following week (Text Fig. 6 and Table X) marked a further stage in this process. Nitzschia was now richest at 20 fathoms, though its numbers had fallen off greatly, while Leptocylindricus was uniformly rich from surface to 10 fathoms, and more numerous than Nitzschia even at 20 fathoms. At the same time a few chains of Eucampia zoodiacus had appeared at the surface. On August 31st (Text Fig. 8, and Table XII) both Nitzschia and Leptocylindricus were negligible in number at all depths, but Eucampia had increased to 4,000 at the surface. The next week (Plate I, Fig. 1; Plate II, Fig. 3) there was an unexpected fall in the numbers of Eucampia, although they rose again the week after (September 14th) to the same value. This curious fall occurred both at Loch Strivan head and Clapochlar and also at Keppel (see Plate IX, Fig. 17), so that it was not a purely local phenomenon. Eucampia never became rich at or below 5 fathoms and disappeared after this.

\begin{tabular}{|c|c|c|c|c|}
\hline $\begin{array}{l}\text { Depth } \\
\text { in } \mathrm{fm} .\end{array}$ & $\begin{array}{c}\text { Total } \\
\text { Diatoms. }\end{array}$ & $\begin{array}{l}\text { Nitzschia } \\
\text { seriata. }\end{array}$ & $\begin{array}{l}\text { Leptocylindricus } \\
\text { danicus. }\end{array}$ & $\begin{array}{l}\text { Eucampia } \\
\text { zoodiacus. }\end{array}$ \\
\hline 0 & 372 & 202 & 3 & 0 \\
\hline 5 & 331 & 180 & 4 & 0 \\
\hline 10 & 120 & 5 & 0 & 0 \\
\hline 30 & 44 & 0 & 0 & 0 \\
\hline
\end{tabular}

TABLE VII. July 28th.

$\begin{array}{rcccc}\begin{array}{c}\text { Depth } \\ \text { in fm. }\end{array} & \begin{array}{c}\text { Total } \\ \text { Diatoms. }\end{array} & \begin{array}{c}\text { Nitzschia } \\ \text { seriata. }\end{array} & \begin{array}{c}\text { Leptocylindricus } \\ \text { danicus. }\end{array} & \begin{array}{c}\text { Eucampia } \\ \text { zoodiacus. }\end{array} \\ 0 & 4,468 & 2,720 & 150 & 0 \\ 5 & 3,701 & 3,000 & 55 & 1 \\ 10 & 371 & 221 & 6 & 0 \\ 20 & 149 & 123 & 0 & 0 \\ 31 & 47 & 15 & 1 & 0\end{array}$

TABLE VIII. August 3rd.

$\begin{array}{rcccc}\begin{array}{c}\text { Depth } \\ \text { in fm. }\end{array} & \begin{array}{c}\text { Total } \\ \text { Diatoms. }\end{array} & \begin{array}{c}\text { Nitzschia } \\ \text { seriata. }\end{array} & \begin{array}{c}\text { Leptocylindricus } \\ \text { danicus. }\end{array} & \begin{array}{c}\text { Eucampia } \\ \text { zoodiacus. }\end{array} \\ 0 & 4,339 & 4,000 & 254 & 2 \\ 5 & 3,970 & 3,900 & 3 & 0 \\ 10 & 1,337 & 1,312 & 3 & 0 \\ 20 & 203 & 171 & 14 & 0 \\ 31 & 111 & 100 & 2 & 0\end{array}$


TABLe IX. August 13th.

$\begin{array}{rrrrc}\begin{array}{c}\text { Depth } \\ \text { in fm. }\end{array} & \begin{array}{c}\text { Total } \\ \text { Diatoms. }\end{array} & \begin{array}{c}\text { Nitzschia } \\ \text { seriata. }\end{array} & \begin{array}{c}\text { Leptocylindricus } \\ \text { danicus. }\end{array} & \begin{array}{c}\text { Eucampia } \\ \text { zoodiacus. }\end{array} \\ 0 & 10,459 & 800 & 9,600 & 12 \\ 5 & 9,633 & 6,300 & 3,200 & 31 \\ 10 & 10,511 & 10,100 & 1,216 & 25 \\ 20 & 781 & 700 & 23 & 0 \\ 31 & 160 & 152 & 2 & 0\end{array}$

TABLE X. August 20th.

$\begin{array}{ccrcc}\begin{array}{c}\text { Depth } \\ \text { in fm. }\end{array} & \begin{array}{c}\text { Total } \\ \text { Diatoms. }\end{array} & \begin{array}{c}\text { Nitzschia } \\ \text { seriata. }\end{array} & \begin{array}{c}\text { Leptocylindricus } \\ \text { danicus. }\end{array} & \begin{array}{c}\text { Eucampia } \\ \text { zoodiacus. }\end{array} \\ 0 & 8,256 & 80 & 8,100 & 65 \\ 5 & 8,377 & 128 & 8,200 & 40 \\ 10 & 9,229 & 296 & 8,900 & 14 \\ 20 & 3,550 & 1,500 & 2,000 & 18 \\ 30 & 451 & 338 & 87 & 1\end{array}$

TABLE XI. August 26th.

$\begin{array}{ccccc}\begin{array}{c}\text { Depth } \\ \text { in fm. }\end{array} & \begin{array}{c}\text { Total } \\ \text { Diatoms. }\end{array} & \begin{array}{c}\text { Nitzschia } \\ \text { seriata. }\end{array} & \begin{array}{c}\text { Leptocylindricus } \\ \text { danicus. }\end{array} & \begin{array}{c}\text { Eucampia } \\ \text { zoodiacus. }\end{array} \\ 0 & 323 & 25 & 181 & 81 \\ 5 & 283 & 24 & 227 & 9 \\ 10 & 561 & 53 & 474 & 5 \\ 20 & 665 & 255 & 385 & 1 \\ 30 & 247 & 169 & 60 & 0\end{array}$

TABLE XII. August 31st.

$\begin{array}{ccccc}\begin{array}{c}\text { Depth } \\ \text { in fm. }\end{array} & \begin{array}{c}\text { Total } \\ \text { Diatoms. }\end{array} & \begin{array}{c}\text { Nitzschia } \\ \text { seriata. }\end{array} & \begin{array}{c}\text { Leptocylindricus } \\ \text { danicus. }\end{array} & \begin{array}{c}\text { Eucampia } \\ \text { zoodiacus. }\end{array} \\ 0 & 4,371 & 0 & 3 & 4,200 \\ 5 & 74 & 4 & 15 & 40 \\ 10 & 83 & 13 & 34 & 11 \\ 20 & 179 & 89 & 70 & 3 \\ 29 & 81 & 54 & 19 & 0\end{array}$

The agreement between the different factors and the diatoms was not so well shown during the early part of this period, the effect of Nitzschia and Leptocylindricus being small and that of Eucampia very large. There is no obvious relation to temperature, though in the surface layers this remained high. $\mathrm{pH}$ value kept high and the surface layer supersaturated with oxygen till Nitzschia reached its maximum, when there was a further increase. The high $\mathrm{pH}$ value was maintained during the 
maximum of Leptocylindricus and phosphate fell definitely. There was a fall in $\mathrm{pH}$ value and dissolved oxygen saturation and a rise in phosphate in the week when diatoms were low between the Leptocylindricus and Eucampia increases, but when this last diatom appeared in numbers the $\mathrm{pH}$ value and dissolved oxygen saturation rose almost as high as during the spring maximum and phosphate was completely utilised.

The following week there was an unexpected rise in $\mathrm{pH}$ value, which had reached its maximum for the year ( $\mathrm{pH} 8.46$ ), although diatoms had decreased and oxygen saturation had fallen considerably. It looks as if oxygen were more sensitive to change than $\mathrm{pH}$ value. Meanwhile, phosphate had remained at zero. At 5 fathoms there was the same general agreement shown with the first two diatoms; the $\mathrm{pH}$ value remained high, the oxygen saturation rose and phosphate fell. Eucampia, as might be expected from its small numbers, shows no effect at or below 5 fathoms.

At 10 and 20 fathoms there were some peculiarities. The sharp peaks at these depths on the 20th August correspond to peaks in the temperature curves. This was a day on which a south-west wind of force 5 was blowing, and was by far the roughest day on which the loch was worked. Wind is a cause of mixing and, as these peaks show on all the curves, it seems probable that they are related to this rather than to photosynthesis alone.

This diatom-rich period confirms the fact, observed first in spring, that a diatom increase appears first at the surface and then at successive depths. It is also remarkable because the diatoms composing it come, not together, but successively, each appearing as the previous one has left the surface and sunk to deeper layers.

Judging from numbers alone one would have supposed that the Nitzschia and Leptocylindricus increases formed the autumn maximum, but when $\mathrm{pH}$, dissolved oxygen, and phosphate values are taken into account it is seen that Eucampia, although lowest in number, has an effect comparable only to that of the spring increase.

October 5 th-December $2 n d$. This was the last diatom maximum. On October 5th there was a very small increase of Rhizosolenia setigera to nearly 500 in the surface layer only, but the species had disappeared the following week. $\mathrm{pH}$ and dissolved oxygen saturation values at the surface rose, and phosphate fell to correspond, but no effect was shown in deeper layers. There was on this day a small rise both in air and sea-surface temperatures, and part of the phosphate fall may be due to the exceptionally low salinity.

On October 12th and 19th the surface temperature fell sharply, and by November 3rd the temperature gradient was reversed and the warmest water was at the bottom. On this date the bottom temperature reached 
its maximum for the year $\left(11.91^{\circ} \mathrm{C}\right.$.), and thereafter began to fall. On October 27 th in the bottom layer there was a rise in the $\mathrm{pH}$ value and dissolved oxygen content and a fall in phosphate, which became still more marked the next week. On November 3rd the other curves also indicate a general mixing.

During these weeks Skeletonema costatum appeared at the surface again, but only in small numbers (100-300). A few were present at 5 fathoms, but the numbers in depths below this never rose above 120. Occasional chains of Skeletonema were met with during the summer, most often in deep-water samples, so it is possible that the slight autumnal rise was due to spores brought up from the bottom by vertical mixing.

Plate II, Fig. 3 shows those diatoms which formed an important increase, but there were, of course, many other species present. The most important was Chcotoceros sociale, which occurred from July till the beginning of October with a maximum of 1,500 on August 2nd at Loch Strivan head. Thalassiosira ( $T$. nordenskioldii and $T$. gravida were the commonest species) is peculiar in that it comes along with Skeletonema, and their numbers during the spring maximum rise and fall together. On May 24th, however, when Skeletonema had almost disappeared, the number of Thalassiosira still rose, and it had its maximum $(1,400)$ at Loch Strivan head, 11 fathoms, that week.

In autumn two species of diatom became abundant in the tow-nettings, although their numbers in the water samples were negligible. These were Melosira sp., common from September 20-28th, and Chatoceros didymum, common from September 22nd till the end of November (with a maximum number of 82 in the water samples).

A comparison of the results obtained at Clapochlar with those at the head of the loch show that there is a general agreement between them (see Plate VIII, Fig. 15 ; Plate IX, Fig. 16). The same diatom increases occurred, and the maxima were generally in the same week. The air temperature (Plate X, Fig. 18) and loch temperature at the head (Plate V, Fig. 9) were somewhat more closely related than at Clapochlar (Plate VI, Fig. 11). pH, dissolved oxygen saturation, and phosphate values agreed except for the third wave of Skeletonema, which had no effect at the head. When the salinity is low the surface $\mathrm{pH}$ and phosphate values are affected by it, the latter being reduced to a low value three times when there were no diatoms to account for it (see Plate VIII, Fig. 14).

The occurrence of dinoflagellates throughout the year is irregular, and they were never numerous except in the surface layer. They appeared and disappeared suddenly, and did not always occur at both stations in the same week, while numbers were higher at Loch Strivan head than at Clapochlar. They caused no noticeable change in $\mathrm{pH}$, dissolved NEW SERIES.-VOL. XIV. NO. 4. MAY, 1927. 
oxygen, or phosphate values. A comparison of salinity (Plate VI, Fig. 10 ; Plate X, Fig. 19), temperature (Plate V, Fig. 9 ; Plate VI, Fig. 11), and dinoflagellates (Plate V, Fig. 8) shows that an increase in dinoflagellates generally coincides with low salinity and a rise in temperature, although there are a few cases in which it is related to low salinity alone or high temperature alone. This agreement is more marked at Loch Strivan head, and as the salinity there is always lower this may explain their greater abundance.

The commonest forms during these increases were the small photosynthetic peridinians. Peridinium triquetra was the most abundant of these, but very often the theca had been discarded, and only a naked brown spore was visible, so that it was impossible to identify the species. $P$. triquetra had its maximum (823) at Loch Strivan head on October 5th. Minuscula bipes was abundant (213) on April 6th at Strivan head, and Diplopsalis spp. at both stations (231 at Loch Strivan head, 99 at Clapochlar) on August 30th and 31st.

The larger species of Peridinium and Ceratium were naturally more abundant in the tow-nettings than in the water samples. Peridinium was common from April onwards, first in the surface nets and later, in November, in the deep nets. Ceratium appeared in numbers in the end of July, and remained abundant till December with a maximum of $C$. longipes in July and of C. tripos in early September and again in November.

Animal life was not abundant in the early part of the year except for rotifers, which were numerous during most of March and April and again in July. Occasional swarms of copepod nauplii and polychæte larvæ were met with during the early months, but the former did not become really abundant till the end of June, along with other planktonic larvæ.

The small copepods, Acartia clausii, Pseudocalanus elongatus, and Oithona similis all occur, being commonest in the deep layers during the summer and autumn. Calanus finmarchicus is the most important copepod. It was common in deep water from May onwards, although catches were rather irregular. Calanus seems to occur in swarms near the bottom of the loch, and the tow-nets probably did not always fish at the right depth and so missed them, even when they were present. The same may be said of adult euphausids, which were occasionally caught in numbers from September 20th. As a rule Calanus is very common at the surface during May and June, but in 1926 it did not appear there.

During June and part of July the large medusæ, Aurelia aurita and Cyanea capillata, were seen in the loch, sometimes in considerable numbers, especially in calm weather. After the middle of July they were not seen, but the stinging threads of Cyanea were still met with on 
hauling up ropes from deep water. After September no traces of these were found.

It was noteworthy that in the deeper layers $\mathrm{pH}$ value and dissolved oxygen saturation fell while phosphate rose from May onwards. The loch had become stable, the thermal gradient to the surface being marked, so that any addition of phosphate to the deeper layers would be cumulative, while a continuous utilisation of this salt in the surface layer kept it at a more or less constant low value. It is probable that this is to be attributed partly to respiration and excretion, and partly to the gradual breaking down of organic material such as dead plants and animals.

The curves for temperature, $\mathrm{pH}$ and phosphate values and dissolved oxygen were very peculiar after October 20th. There was not only mixing, but also a change of the water in the loch. A layer with relatively high $\mathrm{pH}$ and dissolved oxygen values and lower phosphate was introduced at the bottom and spread upwards. Below the surface the temperature was variable, the highest value being found one week at 20 fathoms and later at 5 fathoms. Phosphate, which had accumulated in the loch up till now, was suddenly reduced in quantity, and reached approximately its spring value once more.

Analyses for silicates were made in the surface and bottom samples on most occasions. The silicate content will obviously depend to a considerable extent on the salinity (see p. 842). In spite of this, however, during the spring increases there was a distinct lowering of the silicate at Clapochlar, though this did not show at the head where the river enters. It is extremely improbable that silicates are of importance as a limiting factor in Loch Strivan. Nitrates were estimated in all the samples on most occasions, but very little change was found, and this is probably due to the presence of iron in addition to the traces of nitrites. Nitrites in the loch throughout the year showed no obvious relation to the phytoplankton. During the late spring and in summer and part of autumn the results were of the same nature as those described in 1925 ; that is, higher values were obtained in the deep waters. At the surface the values were generally low during this period. In winter small quantities were found throughout on most occasions. The results are probably associated with the oxygen saturation values, which are low in the deep water, and the occurrence in the surface layer may possibly be due to mixing.

1925 and 1924.

1925. In 1925 five cruises were made over the whole area, in JanuaryFebruary, April, June, August, and October. Eighteen stations were worked each time, one at the head and one in the deepest part of each 
loch, and several in the more open parts of the firth. The positions were the same as those worked by Mill (20) in his survey of the Clyde sea area, and are shown in Text Fig. 1 (p. 839).

January-February cruise. In January and February diatoms were very scarce over all the area. Calanus was present in deep water and sometimes at the surface, while nauplii and other planktonic larvæ were occasionally abundant. During this cruise typical winter conditions were met with; $\mathrm{pH}$ values were much the same from top to bottom, though often there was a slight fall towards the surface due to dilution; dissolved oxygen and phosphate values were similar, the oxygen remaining slightly higher at the surface. Exceptions to this were found in Loch Goil, and, though less marked, in the deep water in Upper Loch Fyne. Loch Goil had hardly undergone any mixing, and was still high in phosphate and low in dissolved oxygen and $\mathrm{pH}$ values in the deep water. This is probably due to the sheltered position of this loch, its depth (47 fathoms) and its shallow threshold (14 fathoms).

April cruise. The April cruise was begun by a visit to the Garroch Head station on April 3rd, immediately after the spring increase of Skeletonema and Thalassiosira had started at Keppel. It was found that diatoms were present there, richest at the surface (over 10,000) and gradually decreasing in the deeper water, while the $\mathrm{pH}$ value was high throughout with a slight rise in the surface layer; down to 10 fathoms the water was super-saturated with oxygen, and the phosphate values were low throughout with a slight gradient to the surface.

In Loch Fyne the next week, the fact that $\mathrm{pH}$ and oxygen values were fairly high throughout and phosphate comparatively low, leads one to suspect that a diatom increase had already passed and that its changes had been distributed throughout all layers by vertical mixing. Diatom numbers were very low, but increased in the deeper layers, especially at Strachur, a condition usually found only after a diatom increase.

In the rest of the area much the same conditions were found; that is, either a diatom increase was going on or had occurred. Where diatoms were abundant there was generally oxygen supersaturation and high $\mathrm{pH}$ and low phosphate values at the surface, while in the deeper layers the changes were similar but less marked. The depths at which changes had occurred agreed with the depths which diatoms had reached.

On several occasions there were marked irregularities in the $\mathrm{pH}$ value, though neither phosphate nor dissolved oxygen values showed corresponding changes. At first it was thought that this might be due to contamination, as it was found at the Gantock Station. Later in the cruise, however, it was met with in Loch Fyne and at Strone Cotes in the Kyles of Bute. Every precaution was taken to prevent accidental contamination and 
the determinations were repeated several times. Only on a few occasions after this was the same phenomenon met with.

Calanus was present in deep water and sometimes at the surface, and occasional swarms of nauplii and other planktonic larvæ were met with.

June cruise. During the June cruises a diatom increase was going on over most of the area. In Loch Fyne and in the Dunoon Basin and the lochs connected with it Skeletonema and Thalassiosira were very abundant. In most cases the surface layers were supersaturated with oxygen, the $\mathrm{pH}$ values high and the phosphate low, and the curves for these generally agreed with the number and position of diatoms. Gareloch head was an exception to this, and here, in spite of a high diatom content, phosphate was high and dissolved oxygen low.

Loch Strivan and the Kyles were visited last, and here, although there were evidences of an increase having passed (there were nearly 3,000 Skeletonema and Thalassiosira at 20 fathoms at Clapochlar), diatoms generally were poor and the predominant species in the surface layers was Chatoceros breve.

Garroch Head station was worked both at the beginning and the end of the cruise, and while Skeletonema predominated at the beginning, C. breve did so at the end.

The most interesting feature of the June cruises was the occurrence of "water bloom" in Loch Long, caused by Peridinium triquetra. When the loch was reached on. June 17th patches of brownish water were seen near the head, but we were informed that they had first been noticed a mile or so further down and had drifted up. The Arrochar Station was worked as usual, and in addition several samples were taken from the coloured patches. In the various surface samples the numbers of $P$. triquetra varied from $32,000-56,000$, and diatoms were extremely scarce. At 3 fathoms, however, $P$. triquetra had fallen to about 800 and diatoms had increased to 23,000 . At 5 fathoms $P$. triquetra were still fewer, and diatoms had fallen again to 750 , while both were still fewer in the bottom sample.

The surface samples were supersaturated with oxygen and the $\mathrm{pH}$ values were very high but variable $(\mathrm{pH} 8 \cdot 37-8 \cdot 51)$, while the phosphate was low at both surface and 5 fathoms. As often occurred in Loch Strivan in 1926, this peridinian increase coincided with low salinity and high temperature in the surface sample.

During the cruise copepods were still numerous, but decreased in numbers towards the end of the month, while at Loch Strivan head and in Loch Ridun thousands of large Aurelia aurita were present.

August cruise. The next cruise was begun in the end of July when Chatoceros sociale was abundart both at Garroch Head and Keppel. 
This species was the predominating form throughout the area except in Loch Fyne, where it was completely absent. There was generally a gradient to the surface shown in $\mathrm{pH}$, phosphate and oxygen saturation. values, the effect being less marked at 5 and 10 fathoms and only slight at and below 20 fathoms. Occasional abrupt changes in $\mathrm{pH}$ value, like those found in April, were encountered. $\mathrm{pH}$ values were often very high (over $\mathrm{pH} 8.30$ ), and the water supersaturated with oxygen even at 5 fathoms. An increase of $C$. sociale was found in some of the lochs (Gareloch, Holy Loch, Loch Ridun), and here the agreement between the diatoms and the chemical factors was fairly good. In the rest of the area, however, numbers were very low and the agreement was not apparent. The results suggest that a diatom increase had just been missed. If this is so, the species was probably $C$. sociale everywhere except in Loch Fyne.

In the enclosed lochs (Loch Long, Loch Goil, and Loch Strivan) dissolved oxygen and $\mathrm{pH}$ values were very low and phosphate high in the deep layers (cf. Loch Strivan, 1926), but in the more open stations and in Loch Fyne this was not found.

Copepods remained numerous in the deep layers generally, and ctenophores (chiefly Bolina infundibulum) were common at most stations.

October cruise. During the October cruise Thalassiosira was the most important diatom. A small increase was in progress throughout the area, and was richest in Loch Long where the number of diatoms rose to 2,700 . The effect on $\mathrm{pH}$, dissolved oxygen and phosphate values was slight even where the diatoms were most numerous.

This month marked a return to winter conditions. The autumn overturn was not complete, although in most cases there was a slight temperature fall to the surface. $\mathrm{pH}$ and dissolved oxygen had fallen from their previous high values and in many cases $\mathrm{pH}$ value was lowest at the surface. Phosphate values in the upper layers continued lower than in the deep water, but were not so low as in summer. In very deep water in the open (e.g. Inchmarnock, $60 \mathrm{mg}$. per cubic metre at 80 fathoms), and in the sheltered lochs, values were very high. In Loch Goil there were $95 \mathrm{mg}$. per cubic metre, and it was high also in Loch Strivan. There was, however, only a slight rise to the bottom in Loch Long and Loch Fyne. Accompanying these very high phosphate values in Loch Goil and Loch Strivan there were low $\mathrm{pH}$ values and very little dissolved oxygen, this reaching a very low value in Loch Goil (1.90 c.c. per litre). Animal life was not very abundant, but there were occasional large hauls of Calanus from deep water. By December at the Garroch Head complete vertical mixing had taken place and diatoms were negligible in numbers.

1924. In 1924 more stations were worked and so each cruise took 
longer, and conditions in one part of the area might differ considerably from those in another during the same cruise.

In January and up till the end of March diatoms were very scarce generally, but Calanus was common in most places and swarms of nauplii and lamellibranch larvæ were often encountered. Loch Fyne proved the most interesting part of the area, for the spring increase had begun there in the first few days of March, and Skeletonema and Thalassiosira were numerous in the water samples. They got richer towards the head of the loch, and there were more than 3,000 in the surface layer at Cuill. Outside Loch Fyne, in the Arran Basin and at Keppel, diatoms were scarce until the 1st April, when there was a sudden great increase. This wave of Skeletonema and Thalassiosira was found also in the Dunoon Basin and Gareloch and probably took place in all the lochs, although these were not visited at this time.

Diatoms were scarce again during April and May, while the tow-nettings were characterised by a great abundance of copepods, especially Calanus, both at the surface and in deep water, but most numerous at the surface. In the end of May, Skeletonema appeared again both at Keppel and in the Dunoon Basin, and was very rich in Loch Fyne.

During August and September an increase of Chcetoceros sociale was going on in the Dunoon Basin and the lochs connected with it and in places, especially at the heads of the lochs, reached very high numbers. At this time, however, there were very few diatoms in Loch Fyne. C. sociale was present in the tow-nets as far up as the Gortans Basin, but was completely absent to the north of this. Copepods were now less common and were found chiefly in deep water.

In the end of September and October, Skeletonema and Thalassiosira appeared again, the latter being more numerous, and there was a small increase of these diatoms all over the area. The largest number of diatoms this year was invariably found at the heads of the lochs, but this was not found in 1925 or 1926 .

At first the $\mathrm{pH}$ value alone was used as a criterion of biological changes in the water, while later organic matter, and in the last cruise dissolved oxygen and phosphate values, were also estimated. Until April the $\mathrm{pH}$ values were almost identical from the top to the bottom except at the heads of the lochs and in Loch Fyne and the Gareloch (very low values were met with in the latter, less than $\mathrm{pH} 7 \cdot 45)$. After April there was generally a gradient from 20 fathoms to the surface with a slight rise even in the deepest layers. Throughout, agreement between the number of diatoms present in water samples and the $\mathrm{pH}$ value was rather sporadic, except in the case of very high $\mathrm{pH}$ values. In many cases no relation appeared to exist. The chief point of interest encountered was that the Gareloch, in spite of low salinity and very low $\mathrm{pH}$ values in winter, had 
the highest $\mathrm{pH}$ value $(\mathrm{pH} 8.50)$ during the increase of Chatoceros sociale in August. The low salinity here and at the heads of lochs seems to favour peridinians, which were often abundant.

Dissolved organic matter, which in the open was generally between 1 and $2 \mathrm{mg}$. per litre, increased towards the heads of the lochs, and in the Gareloch reached over $4 \mathrm{mg}$. per litre at its highest. An examination of the rivers showed that it was present there in larger quantities.

In October the low $\mathrm{pH}$ and dissolved oxygen values and the high phosphate values described in detail for 1926 were met with in Loch Long, Loch Goil, and Loch Strivan, while in the upper layers the $\mathrm{pH}$ value was again approaching its normal winter values.

\section{Annual Changes in the Plankton.}

During these years tow-nettings and water samples were taken twice weekly off Keppel, and some conclusions can be drawn as to the usual course of events (Plate IX, Fig. 17).

There is a well-marked spring diatom maximum which starts at the end of March or the beginning of April. This consists of Skeletonema and Thalassiosira in varying proportions, but with Skeletonema usually predominant. This increase is followed by one or more secondary waves of the same diatoms, which then die away till the autumn. In September or October they increase again, but this autumn maximum varies greatly in amount, probably depending on summer conditions. In 1923 it was large and early (mid-September), and in 1926 small and late. Thalassiosira was as important as Skeletonema in every year but 1926 .

Besides these there is a summer diatom maximum. In 1923 it came in July, and consisted of Rhizosolenia fragillima, but in the other years it was in August. Chatoceros sociale was the predominant form in 1924 and 1925, but in 1926, as has already been described, three species became numerous one after the other.

The larger dinoflagellates (e.g. Ceratium and some species of Peridinium) have their maximum usually in August, but the distribution of the naked forms and of some of the photosynthetic peridinians (e.g. P. triquetra, Glenodinium trochoideum) is less regular, and may depend on external conditions such as temperature and salinity.

In May and June, and sometimes in April, Calanus usually becomes abundant in the surface waters, and tow-nettings from deep water are then less rich than those from the surface. This involves a complete change of habit, for during the rest of the year, except at night, rich hauls are taken only from deep water. In 1926 they never became numerous at the surface, but in 1923, 1924, and 1925 they did, and the phenomenon has been observed elsewhere (Herdman, 12). 
The changes occurring at Keppel are, on the whole, the same as the changes in the rest of the Clyde area, Loch Fyne being the only exception. The lochs, however, show a certain independence. In 1926 the spring increase began in Loch Strivan a day or two before any rise in numbers took place at Keppel, and this was the case also with the increase of Eucampia. Leptocylindricus was much more numerous in Loch Strivan than it ever was at Keppel. Some species, too, seem to be almost restricted to one loch, e.g. Tintinnus steenstrupii is very rare, and the copepod Euchata norvegica is rare, outside of Loch Fyne. In 1926 Dinophysis hastata was recorded first and became common in Loch Strivan, while it only appeared in small numbers later at Keppel.

Loch Fyne shows'the greatest divergences from the rest of the area. It appears to have an earlier spring maximum (this was only found in 1924, but the results from the April cruise in 1925 indicated that it had taken place in that year too), and Chotoceros sociale hardly appeared there although abundant in the rest of the area.

\section{DISCUSSION.}

A comparison of the diatom curves with those for $\mathrm{pH}$ value, dissolved oxygen saturation and phosphate content shows a striking agreement in the surface layer (see Plate II, Figs. 3 and 4 ; Plate III, Figs. 5 and 6). An agreement though less marked is shown at 5 fathoms, still less at 10 fathoms, and only slightly at 20 fathoms. When, however, the curves are carefully followed it becomes apparent that this agreement is not close when numbers of diatoms alone are considered. For example, Chætoceros and Eucampia had an effect which would not be expected on the basis of numbers alone. The highest $\mathrm{pH}$ value for the year was reached during the increase of the latter diatom, which only attained a maximum number of about 4,000 chains in 20 c.c. Nitzschia and Leptocylindricus, on the other hand, had a comparatively small effect in spite of their larger numbers. Another point of apparent disagreement in the curves is the delay in reaching a maximum value in the case of $\mathrm{pH}$ or dissolved oxygen saturation value, or a minimum in the case of phosphate when compared with diatom numbers. From this point of view still more frequent visits to the loch would have been interesting, and it is to be expected that a comparison every one or two days would have eliminated this apparent lag. Naturally all changes in number of diatoms and other factors are minimal, since in the course of a week (the usual interval between visits) it is quite possible for important changes to occur. There are two points on the curves, however, which require further mention. The first is the high surface $\mathrm{pH}$ value on July 14th. This is two weeks after the date of maximum number of diatoms for this 
increase, and it is possibly related to the temperature, which reached its maximum for the year on that date. The other is the high $\mathrm{pH}$ value on September 7th. While this might be due to the apparent lag described above, it is surprising that oxygen saturation value does not agree with it. The number of diatoms had fallen considerably, and the phosphate remained at zero. It is probable that in the surface layer dissolved oxygen saturation tends to approach 100 per cent more readily than $\mathrm{pH}$ value tends to fall. This will depend on the state of the sea, e.g. a choppy day would reduce supersaturation rapidly. At 5 fathoms, and to a less degree at 10 fathoms, the same changes take place a week later than at the surface. This is in accordance with the sinking of the diatoms during an increase. The changes were slight at 20 fathoms, and may have been due there (and perhaps in a less degree at 10 and 5 fathoms also) to mixing with the upper layers. As this was the case in other years also, it is likely that a depth between 10 and 20 fathoms is the limit for photosynthesis in the area.

Although sunlight is necessary for photosynthesis, too much of it is injurious. It has been found that diatom cultures grow best away from direct sunlight, and experiments at Millport have shown that, of two series of bottles of diatom culture at the same temperature, one placed in full sunlight and the other in the shade, the second will produce oxygen while the first will not and may even use it up. Even in the sea, it is possible that in summer the actual surface layer is not the optimum position for diatoms. During the increase of Nitzschia and Leptocylindricus the diatom cells in the surface sample looked pale and unhealthy with the chromatophores contracted, whereas the cells from 5 fathoms and deeper layers were perfectly normal. The same has been observed by Schimper (Karsten, 1905, 14). In spite of this, however, photosynthesis, as measured by the change in $\mathrm{pH}$, oxygen and phosphate values, was always most active at the surface. In early September, Eucampia became very rich in the surface layer, and was present in smaller numbers at 5 fathoms, but not below this. It is possible that at this time the decreasing light was limiting its development below the surface, and the same may be said of Rhizosolenia and Skeletonema.

At Plymouth (6) and Port Erin (11) the date of the spring maximum has been shown to depend largely on the amount of sunshine in the early part of the year. Conditions in this area are different. Text Fig. 9 shows the monthly averages of hours of sunshine for the years investigated, and it will be seen that the spring maximum (taken as the date on which there were 500 diatom chains in 20 c.c.) comes at almost the same date each year and actually latest in the year with most early sunshine, 1924 (see also Plate IX, Fig. 17). In Loch Fyne in that year it began nearly a month earlier than at Keppel, so it appears that in this area the amount 
of sunlight is not the factor which starts off the spring increase. A measurement of the total amount of incident light and not only sunshine would be a more reliable guide. A comparison may perhaps be drawn between the growth of a diatom culture in the laboratory in winter and the early diatom increase in the enclosed waters here.

The spring increase is almost certainly not a direct effect of temperature rise, as is shown by Plate II, Fig. 3, and Plate VI, Fig. 11, and this has already been suggested by other workers. It was well under way before temperature rose.

A comparison of the number of diatoms found in the area with the numbers found in the open sea shows a very great difference. The

$10^{-}$

$-10$

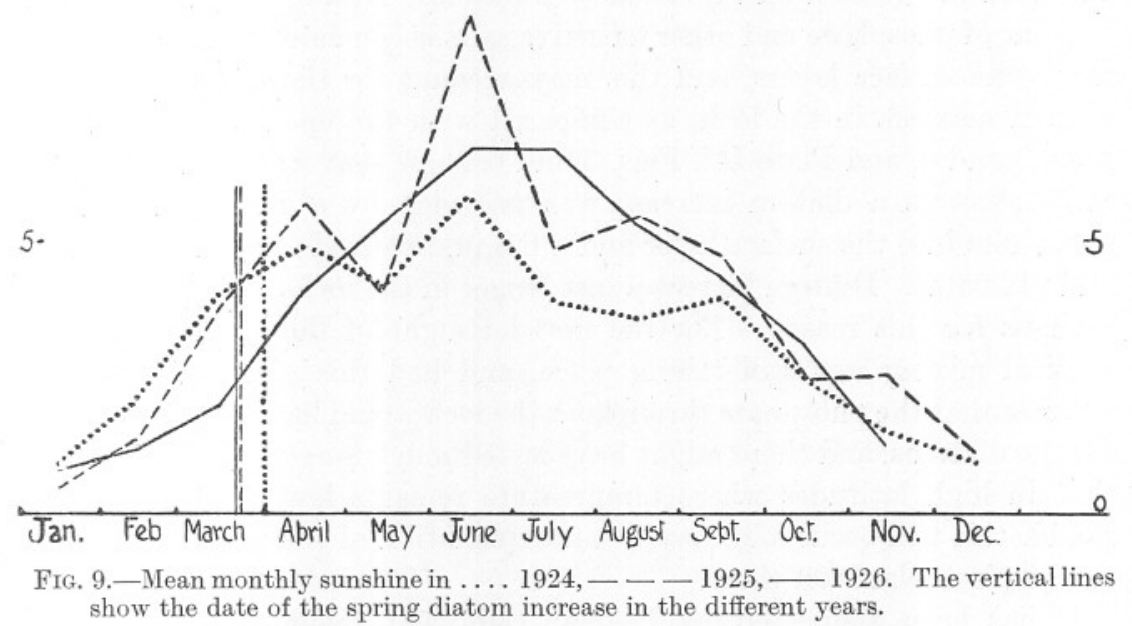

numbers here are very much greater, and are comparable to those found by Lohmann (18) at Kiel, although an exact comparison is not possible since they were not counted in the same way. Results for $\mathrm{pH}$ value and dissolved oxygen saturation bring out this difference clearly. The winter values for phosphate are not very different from those for the open sea, but mixing renders this salt available for plant growth much more readily than there.

Vertical mixing due to temperature gradient is not so important in the area, for the winter rains affect the salinity at the surface (see Plate VI, Fig. 10 ; Plate VII, Fig. 12 ; Plate X, Fig. 19), and the density is not the same throughout. On the other hand, the effect of wind and tide is much more marked. Tide may cause mixing in the manner described by Huntsman (13), while the important effect of wind for Loch Strivan among other lochs has been shown by Murray (21). 
When the temperature curve for 1926 is compared with those for $\mathrm{pH}$, dissolved oxygen saturation and phosphate values (Plate VI, Fig. 11 ; Plate II, Fig. 4 ; Plate III, Figs. 5 and 6), it is found that the dips in the curves occur on the same date in all. When it is compared with the diatom curve, however, it is found that except in a few cases (Chatoceros cinctum in May and Cerataulina in July) the increase in diatoms does not coincide with a rise in temperature. The similarity is probably to be explained by the fact that a certain amount of mixing had been going on. The curves for different depths have approached one another, i.e. the values have been more evenly distributed throughout. This mixing is more marked at Loch Strivan head than at Clapochlar (see Plate V, Fig. 9; Plate VIII, Fig. 14), as might be expected from its situation at the head of the loch and its shallower waters. By this means a certain amoint of phosphate and other nutritive salts is constantly being brought up to the surface layers, and this may account for the more numerous diatom maxima in the loch, as compared with the open sea. Plate II, Figs. 3 and 4, and Plate III, Figs. 5 and 6 , show that with the exception of Chætoceros a diatom increase was preceded by a reintroduction of phosphate into the surface layer and a fall in dissolved oxygen saturation and $\mathrm{pH}$ value. Diatom increases last longer in the lochs than at Keppel, perhaps for this reason. For the first fortnight of the spring increase, vertical mixing was still taking place, and had this gone on it seems possible that the phosphate throughout the loch would have been available for the diatoms, and these might have lasted much longer. It is probable that in high latitudes where temperature remains low the whole year round, this will occur and may be an explanation of the greater richness of the phytoplankton there.

It has been suggested by Pearsall (26) that the heavy rainfall in spring and autumn increases the amount of nutritive salts brought into the sea by rivers and is sufficient to cause an increase in diatoms. On p. 842 it has been shown that little phosphate is introduced by the rivers, although silicates, and possibly other compounds, are rich. When the rainfall curve for 1926 was compared with those for salinity and for diatoms in Loch Strivan it was found that while salinity and rainfall are related, there was no relation between rainfall or salinity and diatom increases. Occasionally when the surface water was discoloured and the salinity very low (as on August 19th at Loch Strivan head) diatoms were exceedingly scarce in this layer and small photosynthetic dinoflagellates abundant. The absence of diatoms may be due simply to the fact that a layer of low salinity has been added at the top and the diatom rich layer is therefore found at a greater depth than before, a depth which may not have been sampled. Since, as a rule, samples were only taken at surface, 5, 10, 20 and 30 fathoms, 
it is of course always possible that a layer rich in diatoms or other organisms may have been missed entirely, but from the consistent results and their agreement with the chemical factors this does not seem probable (see also p. 857).

One observation which has been made frequently during 1926 is that a diatom increase begins in the surface layer and spreads downwards, decreasing at the surface as it does so. This was first observed by Lohmann (18) at Kiel, and was inferred by Gran (8) from the conditions found in the north European waters. Exceptions to this rule are found in the increases of Chatoceros cinctum and Eucampia, although as stated above the latter may be due to autumnal light conditions. This spreading downwards is seen most clearly in the spring maximum, where it seemed to depend on the amount of phosphate present. The spring increase lasted the longest time, and in increases after this the diatoms spread downwards more rapidly. This agrees with the consistently low phosphate values in the surface during the summer. The higher temperature too may increase the rate of metabolism of the diatoms, and so cause the change to occur more rapidly. It may also be due, as Gran has suggested, to the lower viscosity of the water then. In August and September, however, the sinking is probably not due to low phosphate value, for as soon as one diatom had decreased in the surface layer another appeared there. It would seem either that each diatom depends on minute amounts of a substance, the particular substance varying with each species of diatom, or else that there is an internal factor which is not yet known. The first alternative is suggested by Overton's (24) analyses of some closely related species of Fucus, which had marked differences in chemical composition in spite of their growing side by side. On the other hand, Nathansohn (22) suggests the possibility that phytoplankton may excrete some substance into the water which is injurious to itself.

Gran and Gaarder (9), working in the Kristiania fjord, attributed sudden changes in the phytoplankton there to the meteorological conditions prevailing at the time. The fjord runs north and south, and with a north wind the surface layers were blown out and replaced by warmer and more saline water from below. A south wind, on the other hand, carried in the diatom-rich surface layers of the sea outside with a consequent welling out of deep water from the fjord. This action caused a great increase of diatoms at the end of March, which sank rapidly into deep water, owing to the continuous southerly wind. Such an explanation does not apply to the changes in Loch Strivan. Plate I, Fig. 2, gives the north and south components of the wind in 1926, and it will be seen that before and at the beginning of the spring maximum there were northerly, i.e. outgoing winds, and although the wind changed to southerly on April 1st this had no obvious effect on the diatoms. As they were 
already rich at 5 and 10 fathoms on this date it is obvious that the sinking was not due to wind action. During the rest of the year no connection can be found between wind direction and the appearance of diatoms.

The hope that this work might give some clue to the cause of the changing species of diatom during the year was not fulfilled. Chætoceros seemed to have a greater power of utilising phosphate than Skeletonema, a power apparently shared only by Eucampia, but this is not borne out by the June cruise of 1925 in Loch Fyne, where an increase of Skeletonema reduced the phosphate to zero on one occasion.

With regard to the effects of animal life and regeneration of phosphate, precise results are not available since the tow-nettings were not quantitative. The curves show that where animal life is rich, dissolved oxygen saturation and $\mathrm{pH}$ value are low and phosphate high, though this is probably due in part to the breaking down of dead organisms.

The total phosphate in solution just before the autumn mixing in Loch Strivan was definitely higher than before the spring diatom increase, and the same phenomenon apparently also occurs in Loch Long and Loch Goil. Each of them seems to form a reservoir of phosphate in its deep waters till the autumn mixing takes place, when the phosphate is distributed and spring values again attained by a change of the water. How the additional phosphate is acquired is not known. This phenomenon does not occur in the more open water of the area where conditions are much more like those described by Atkins (4) for the English Channel.

The writers wish to express their thanks to Mr. Elmhirst, Superintendent, and members of the Staff, for their help throughout.

\section{SUMMARY.}

1. Simultaneous observations are recorded of some biological, physical, and chemical changes in the Clyde Sea Area in 1924, 1925, and 1926 .

2. A close relation between diatom increases and changes in $\mathrm{pH}$ value, dissolved oxygen saturation and dissolved phosphate has been found.

3. It appears that the more numerous diatom increases in Loch Strivan as compared with the open sea are due to the more frequent mixing.

4. Confirmation of the fact that diatom increases begin at the surface and gradually spread into deeper water has been obtained.

5. The occurrence of Peridinians is apparently related to high temperature and low salinity. 
6. The amount of sunshine in the early part of the year does not exert any apparent influence on the date of the spring diatom increase in the Clyde Sea Area.

7. The regeneration of phosphate in the deep water of Loch Strivan has been described.

\section{REFERENCES.}

1. Atkins, W. R. G. 1922. The hydrogen-ion concentration of seawater in its biological relations, Part I. Journal Marine Biological Association, N.S., Vol. 12.

2. Atkins, W. R. G. 1923. The silica content of some natural waters and of culture media. Ibid., Vol. 13.

3. Atkins, W. R. G. 1923. The hydrogen-ion concentration of seawater in its relation to photosynthetic changes, Part II. Ibid., Vol. 13.

4. Atrins, W. R. G. 1923. The phosphate content of fresh and salt waters in its relationship to the growth of the algal plankton. Ibid., Vol. 13.

5. Atkins, W. R. G. 1925. Seasonal changes in the silica content of natural waters in relation to the phytoplankton. Ibid., Vol. 13.

6. Atkins, W. R. G. 1926. A quantitative consideration of some factors concerned in plant growth in water. Part 2. Journal du Conseil. Vol: I, No. 3.

7. Fox, C. J. J. 1907. The dissolved gases of sea-water. Publications de Circonstance. No. 41.

8. Gran, H. H. 1912. The plankton production of North European waters in the spring of 1912. Bulletin Planktonique.

9. Gran, H. H., and Torbjörn GaARder. 1918. Uber den Einfluss der atmosparischen Veränderung Nordeuropas auf die hydrographischen Verhaltnisse des Kristianiafjords bei Drobak in Marz, 1916. Publications de Circonstance. No. 71.

10. Harvey, H. W. 1926. Nitrate in the sea. Journal Marine Biological Association. Vol. 14.

11. Herdman, W. A., A. S. Scott, AND W. J. Dakin. 1909. Intensive study of the marine plankton round the Isle of Man. Transactions Liverpool Biological Society. Vol. 18.

12. Herdman, W. A. 1918. Distribution of certain diatoms and copepods throughout the year. Journal Linnean Society, Zoology, Vol. 34 . 
13. Huntsman, A. G. 1923. The influence of tidal oscillations on vertical circulation in estuaries. Transactions Roy. Soc. Canada, 3rd Series, Vol. 17.

14. Karsten, G. 1905. Die Phytoplankton des Antarktischen Meeres nach dem Material der deutschen Tiefsee Expedition. 1898-99. Wissenschaftliche Ergebnisse der Deutschen Tiefsee Expedition. Band II. Teil II.

15. Knudsen, M. 1901. Hydrographical Tables. Copenhagen.

16. KNuDsen, M. 1923. Some new oceanographical instruments. Publications de Circonstance. No. 77.

17. Lenormand, C. 1904. A new method for the estimation of organic matters in waters, more particularly in waters containing chlorides and bromides. Chemical News, Vol. 89.

18. Lohmann, H. 1908. Untersuchung zur Feststellung des vollstandigen Behaltes des Meeres an Plankton. Wissenschaftliche Meeresuntersuchungen, v.d. Komm. z. wiss. Unters. d. deutsch. Meere in Kiel. Vol. X.

19. McClendon, J. F. 1917. The standardisation of a new colorimetric method for the determination of hydrogen-ion concentration, etc., of sea-water. Journal of Biological Chemistry, Vol. 30.

20. Mrul, H. R. 1889-91. The Clyde Sea Area. Transactions Royal Society, Edinburgh, Vol. 37.

21. Murray, J. 1888. On the effects of winds on the distribution of temperature in the sea- and fresh-water lochs of the West of Scotland. Scottish Geographical Magazine.

22. Nathansohn, A. 1909. Sur les relations qui existent entre les changements du plankton végétal et les phénomènes hydrographiques. Bulletin de l'Institut Océanographique. No. 140.

23. ORR, A. P. 1926. The Nitrite content of sea-water. Journal of the Marine Biological Association, N.S., Vol. 14.

24. Overton, E. 1907. In Nagel's Handbuch der Physiologie des Menschen, Bd. 2, T. 2, s. 807.

25. Ostenfeld, C. H., and P. Jespersen. 1924. A standard net for plankton collections. Publications de Circonstance. No. 84.

26. Pearsall, W. H. 1923. A theory of diatom periodicity. Journal of Ecology. 

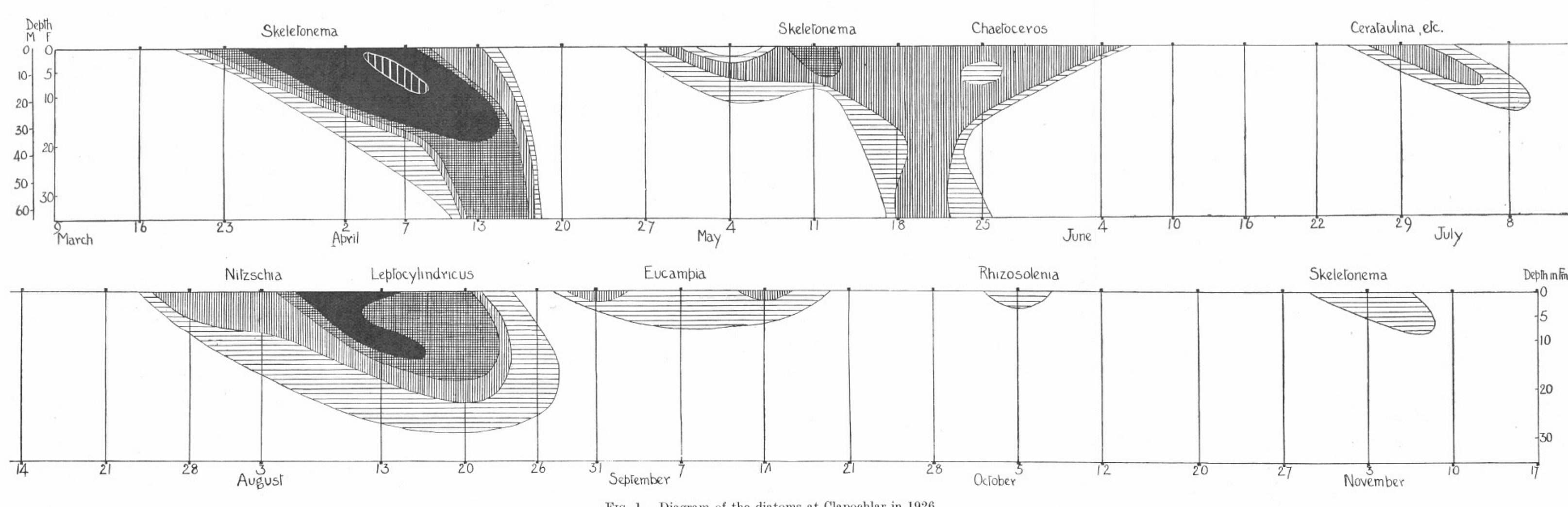

$\square$ under $500, \equiv 500$ to $2,000, \quad$ IIIII 2,000 to $5,000, \quad 5,000$ to $10,000, \quad 10,000$ to 25,000 , IIII over 25,000 , diatom chains in 20 c.c.

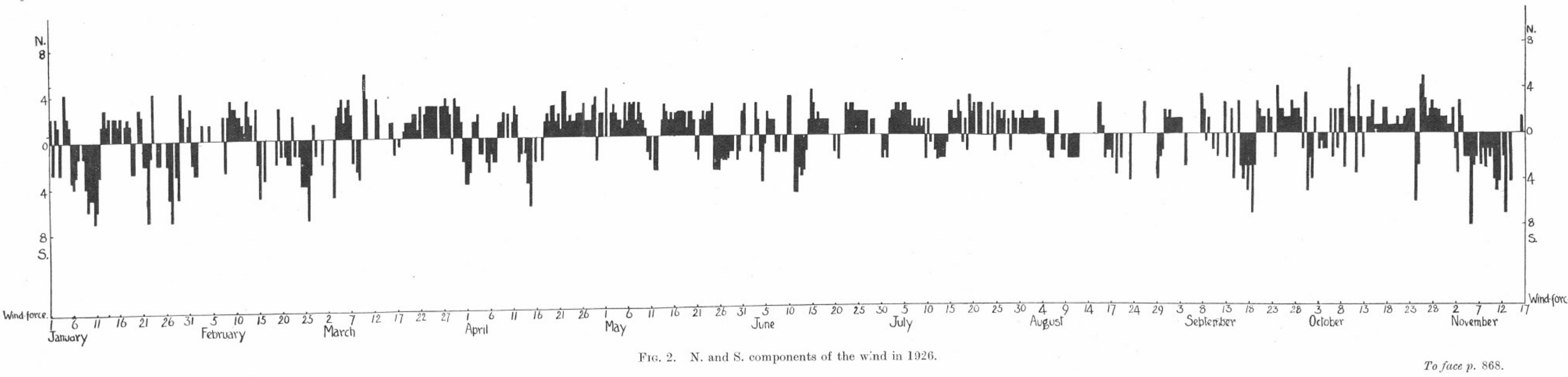




$$
\text { INANMV }
$$




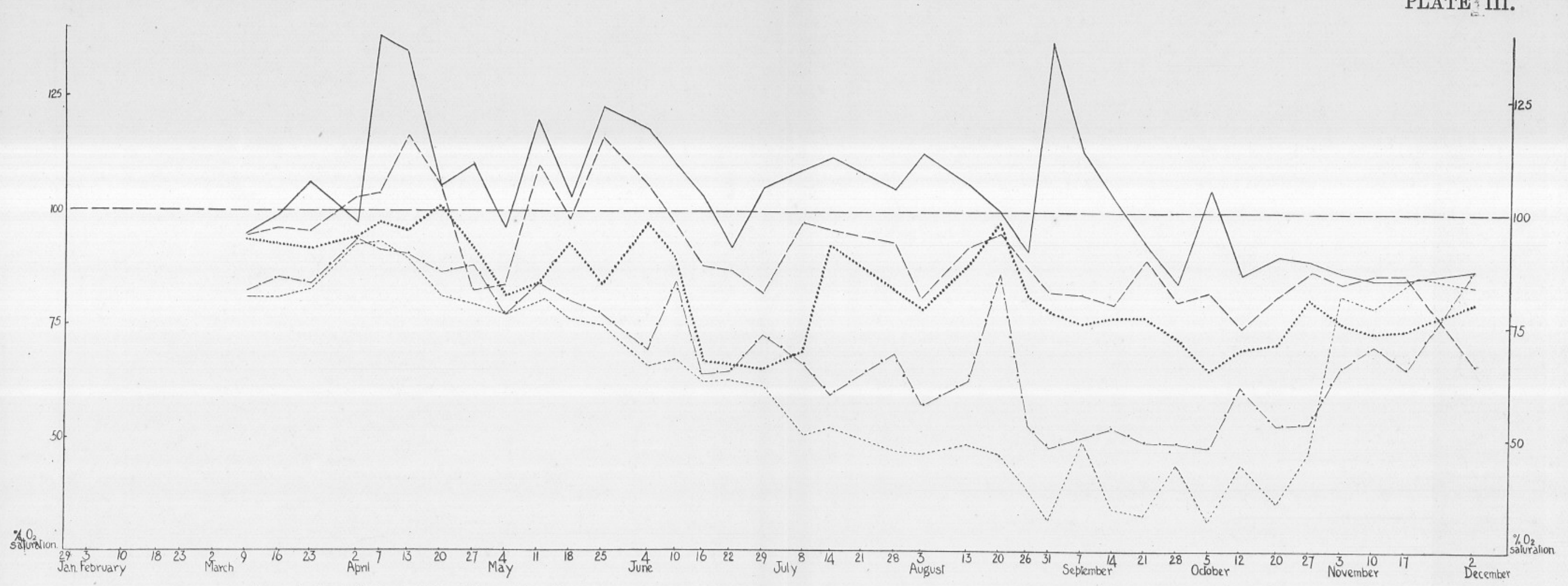

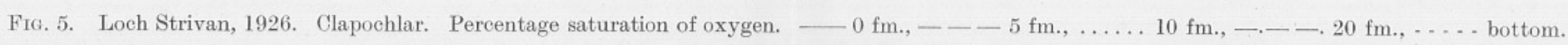

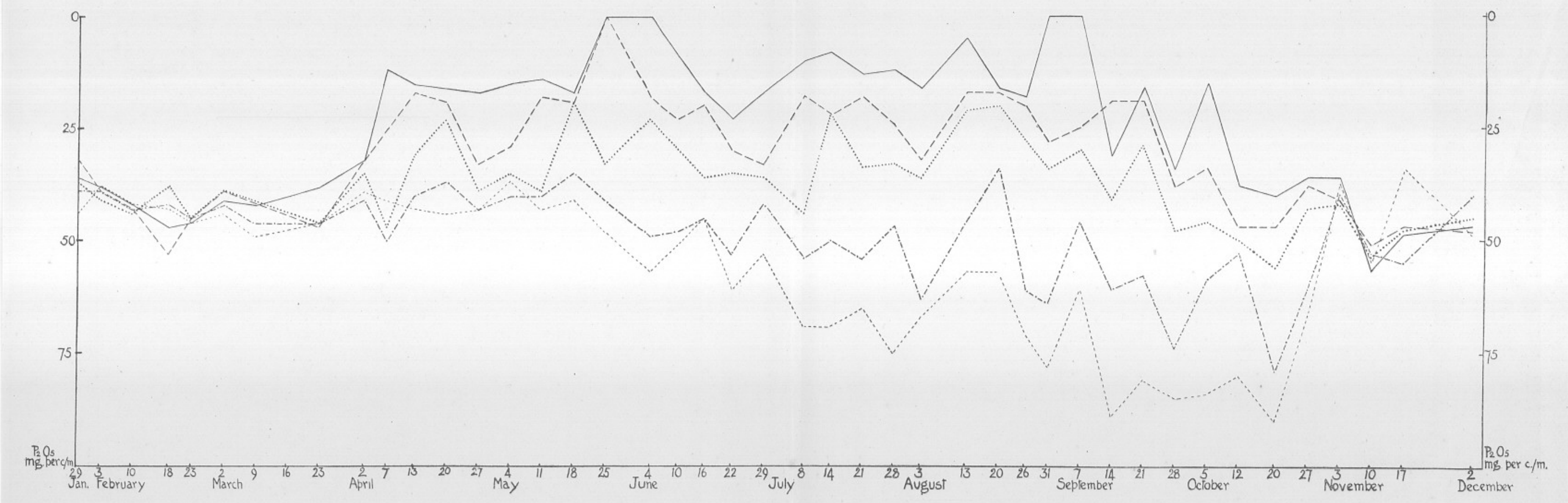

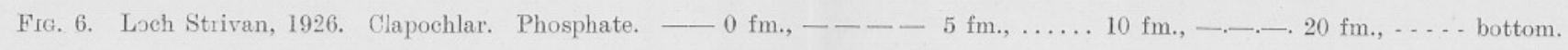


PLATE IV.

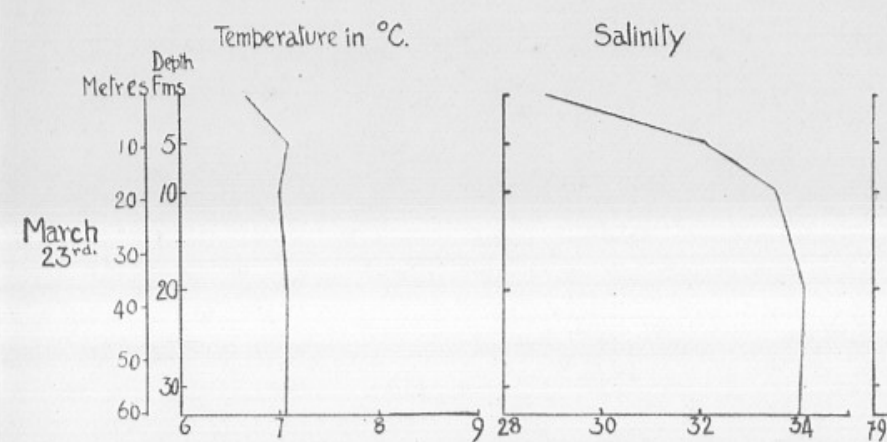

pH. value.

$\% \mathrm{O}_{2}$ saturation.

$\mathrm{P}_{2} \mathrm{O}_{5}$ mg. per cubic metre

Dialom.chains in 20 cc. sea waler.
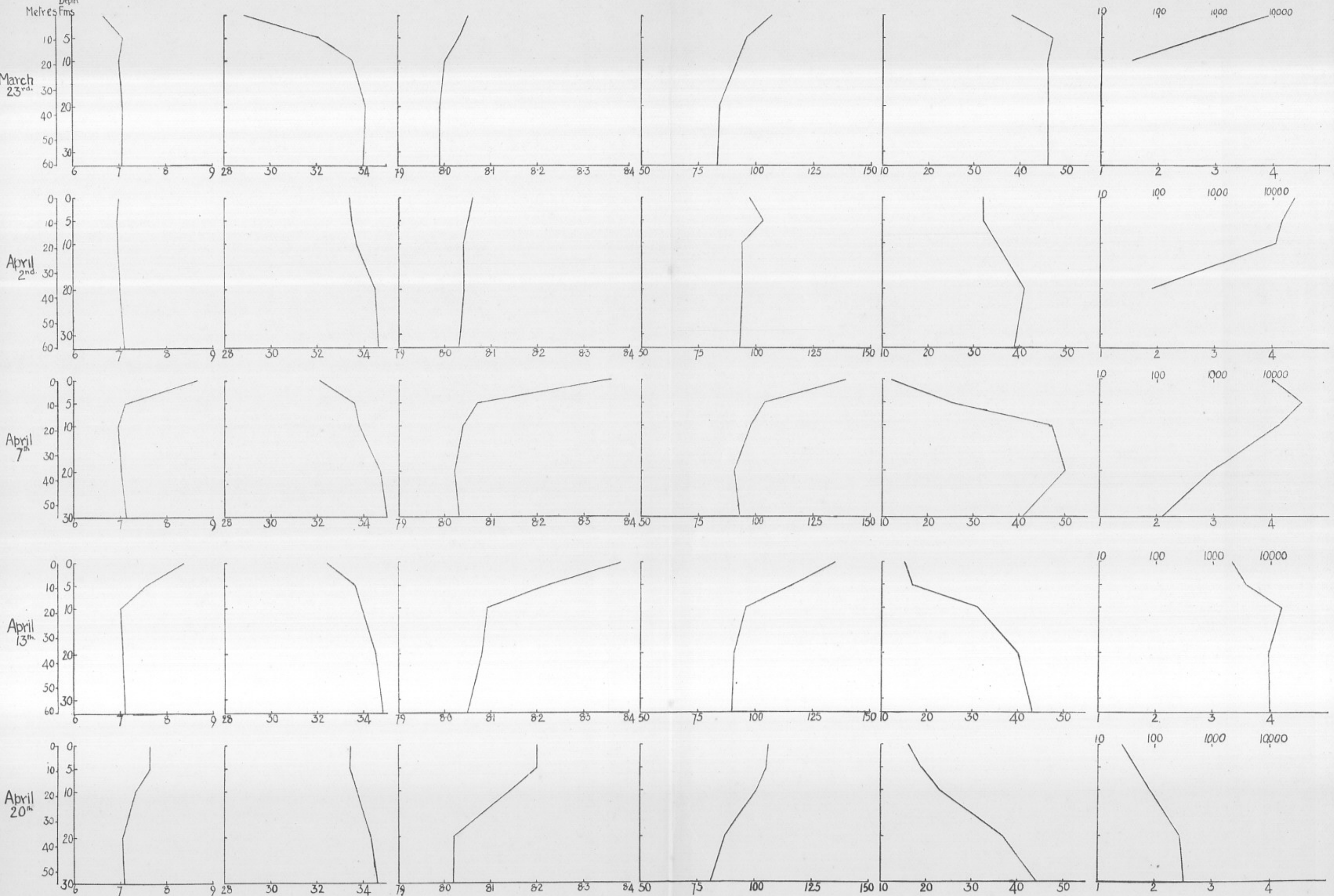

Fig. 7. Lech Strivan, 1926. The changes during the spring diatom maximum. 
PLATE V.
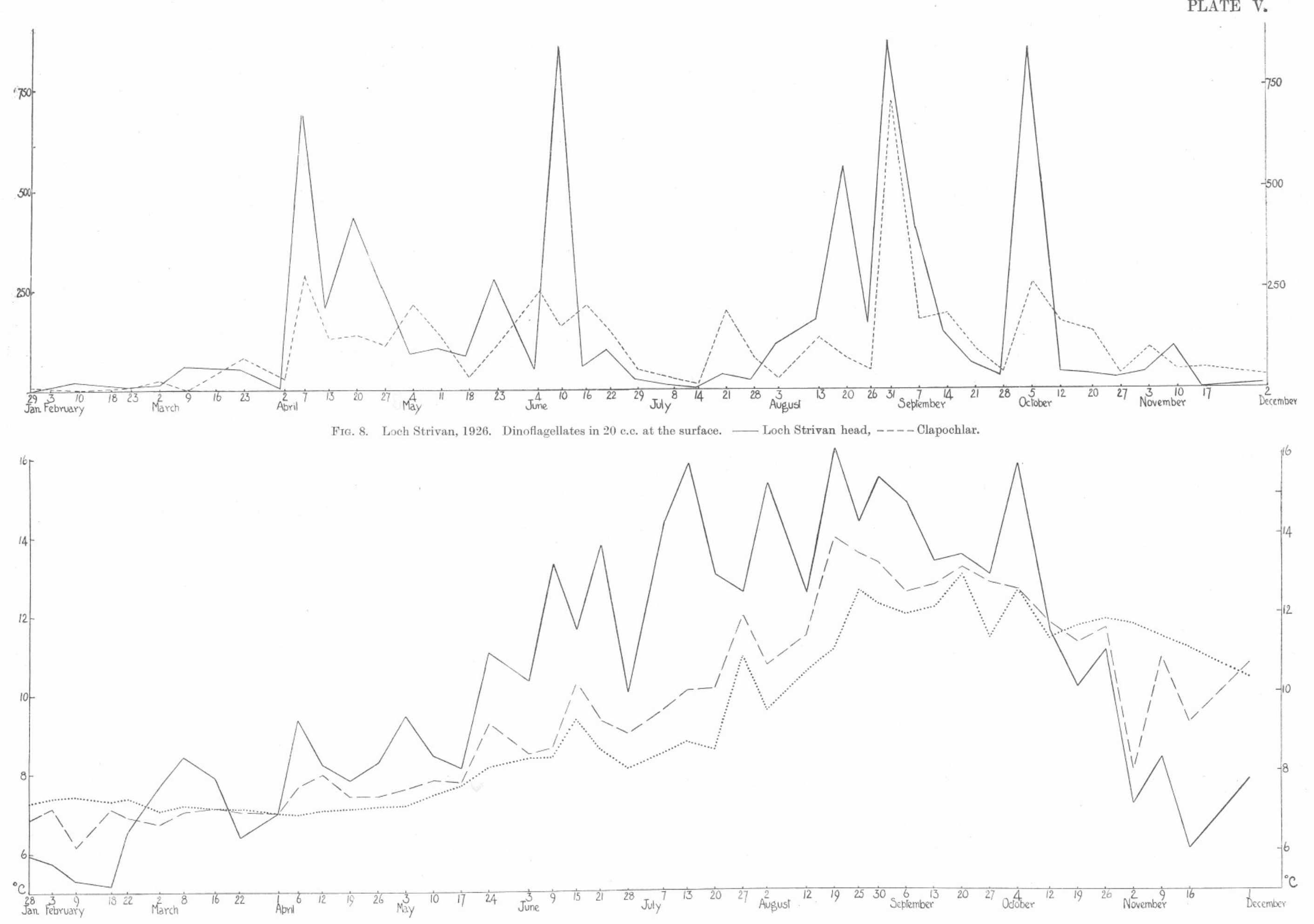

Fic. 9. Temperature at Loch Strivan head, 1926. — 0 fm., $-\longrightarrow 5$ fm., ..... bottom. 
PLATE VI.

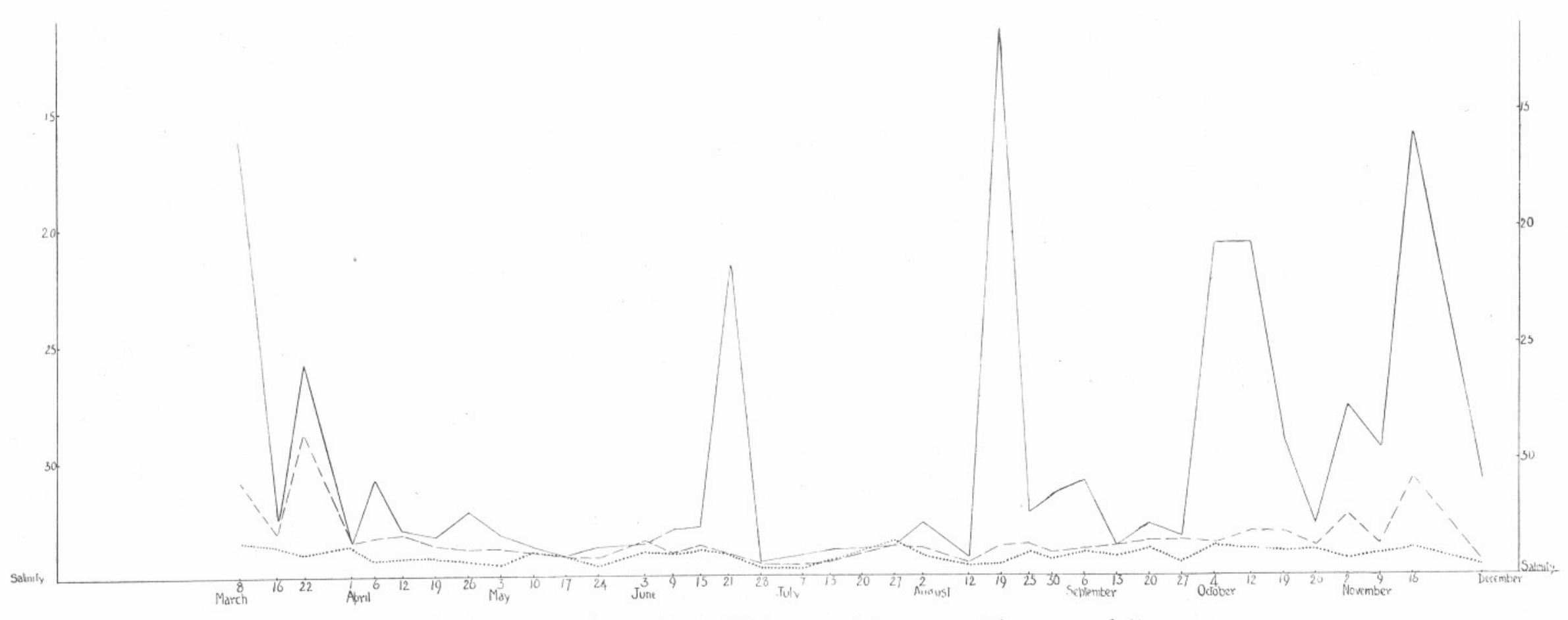

Fig. 10. Loch Strivan, 1926. Head. Salinity. — $0 \mathrm{fm} .,---5 \mathrm{fm} ., \ldots \ldots$ bottom.

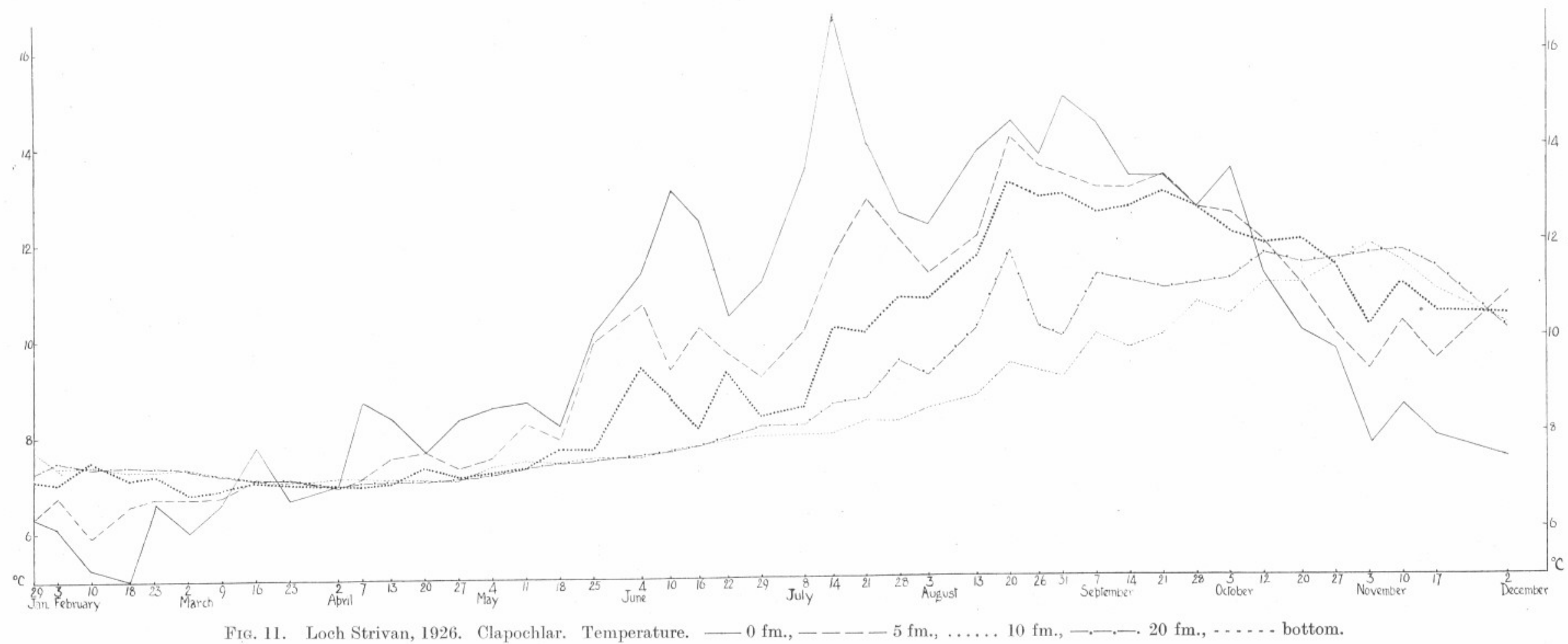



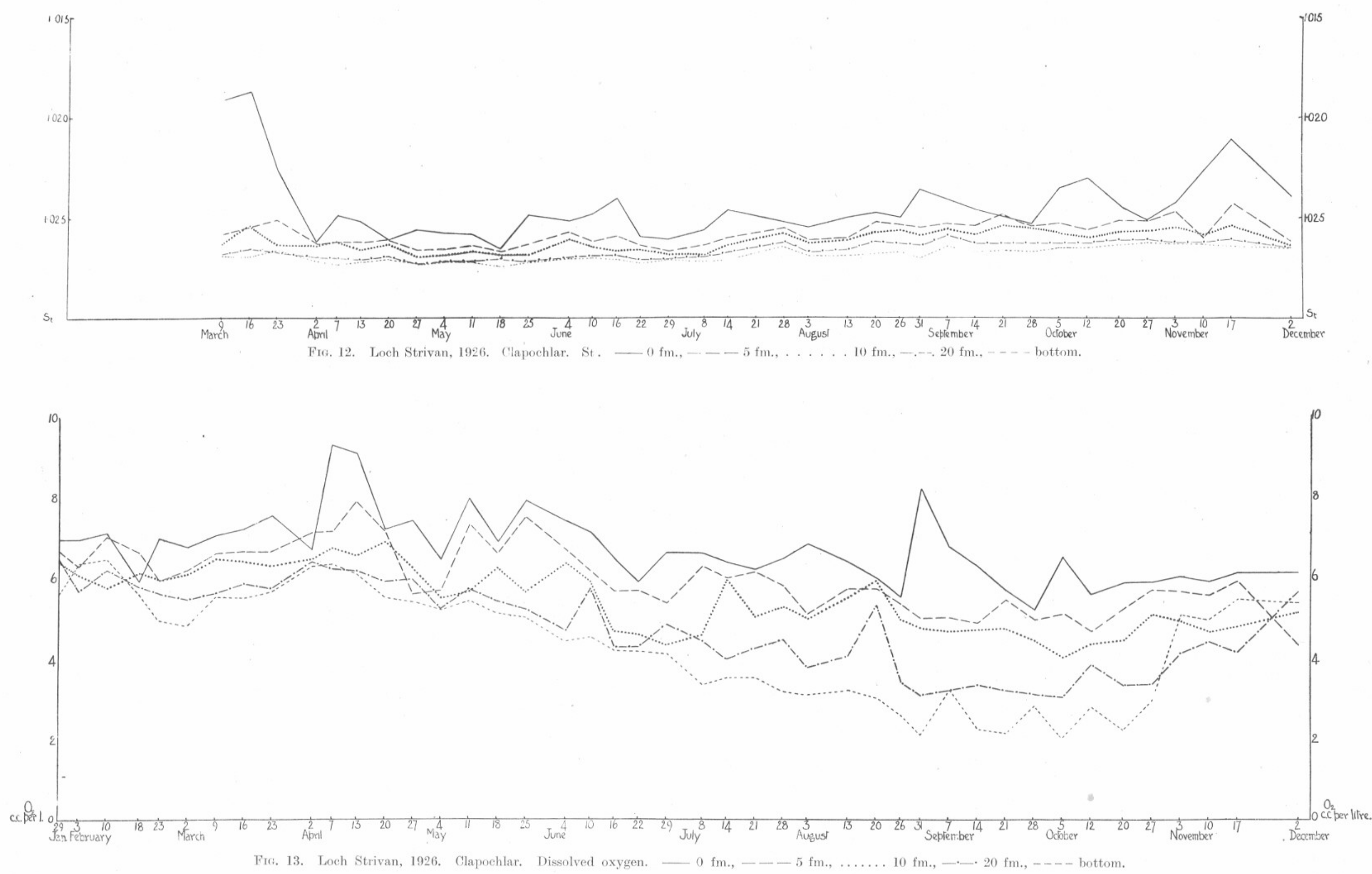

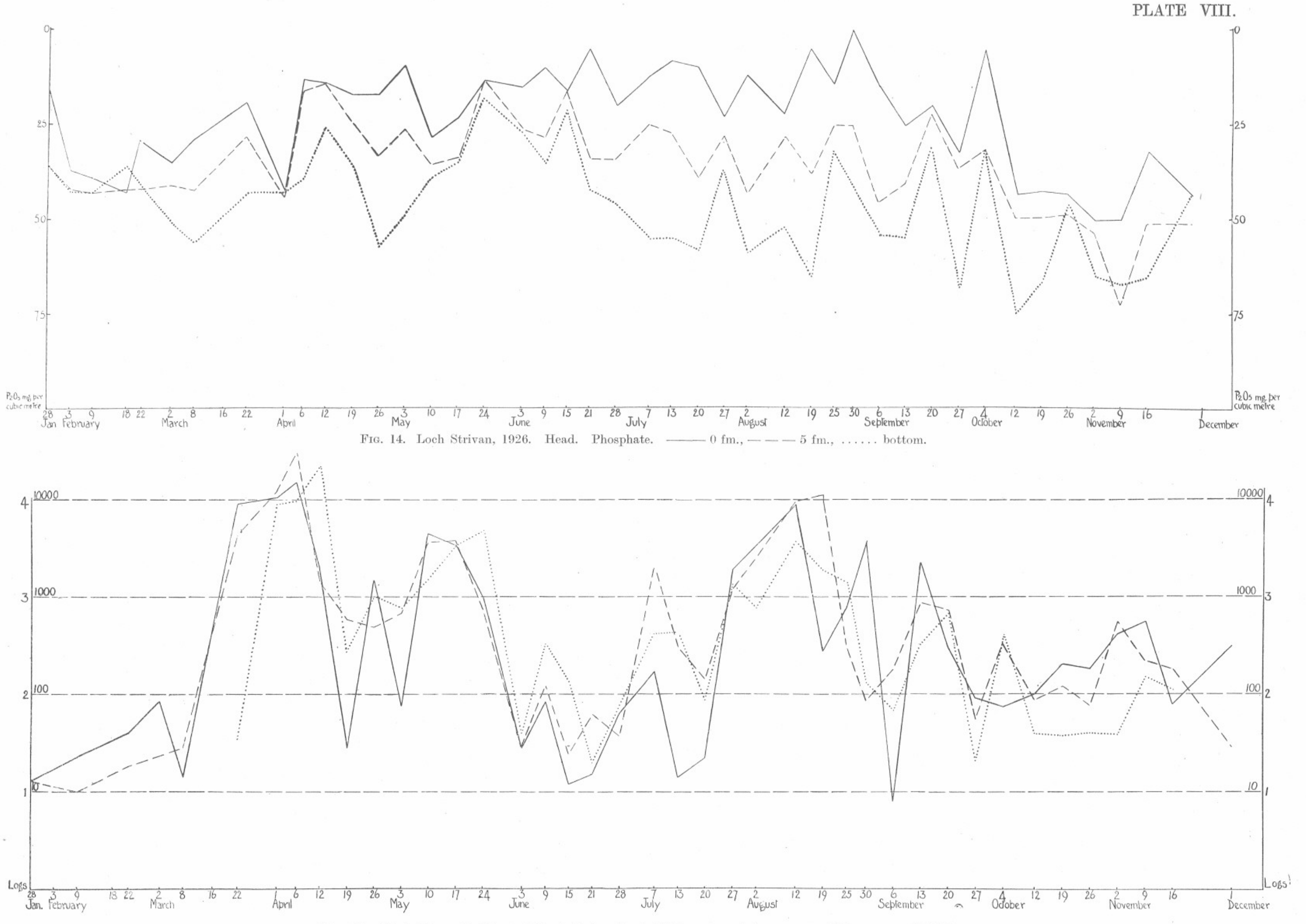

FIG. 15. Total diatoms in 20 c.c. at Loch Strivan head, 1926. $-0 \mathrm{fm} .,--5 \mathrm{fm} ., \ldots \ldots$ bottom. 


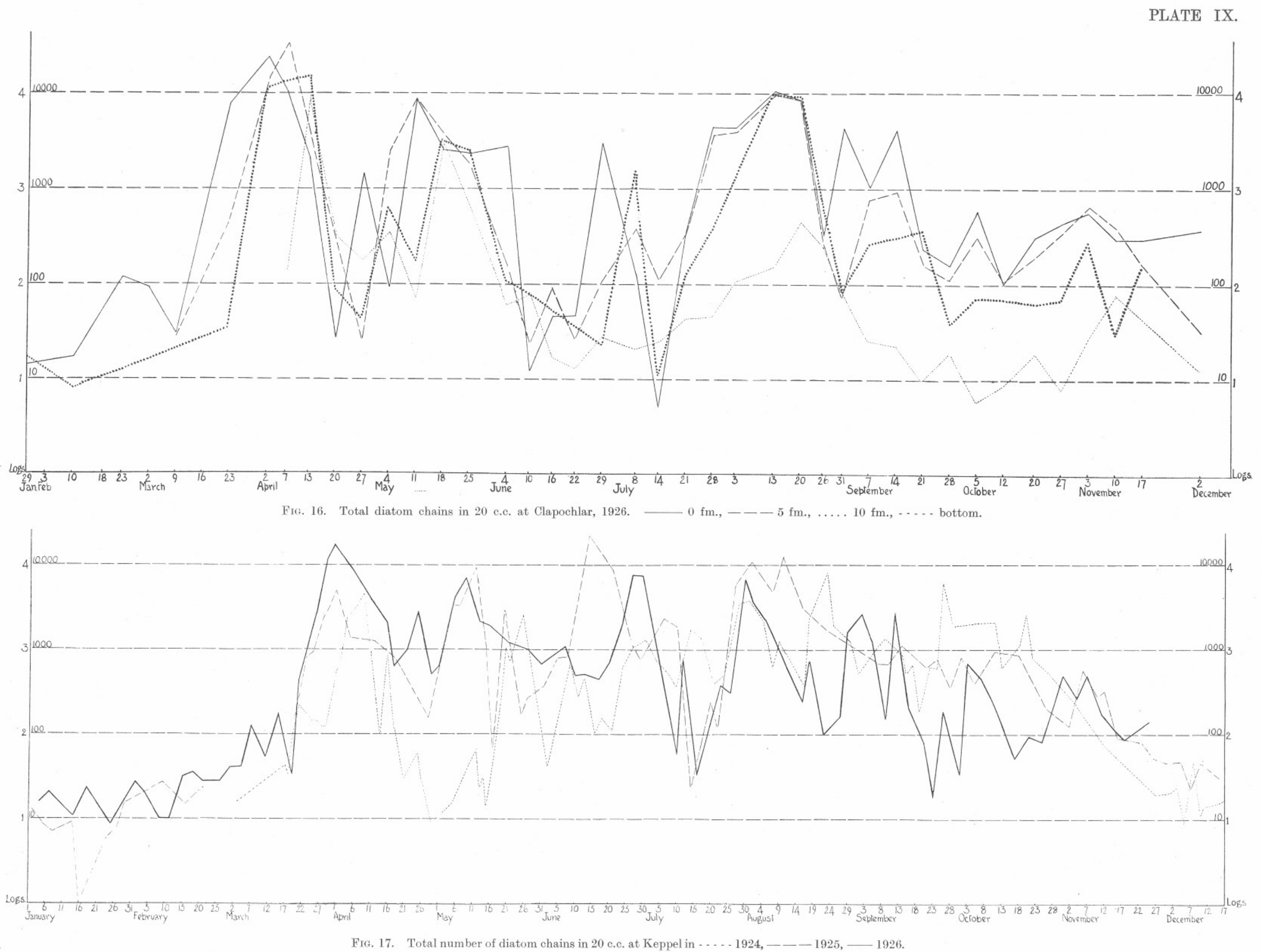



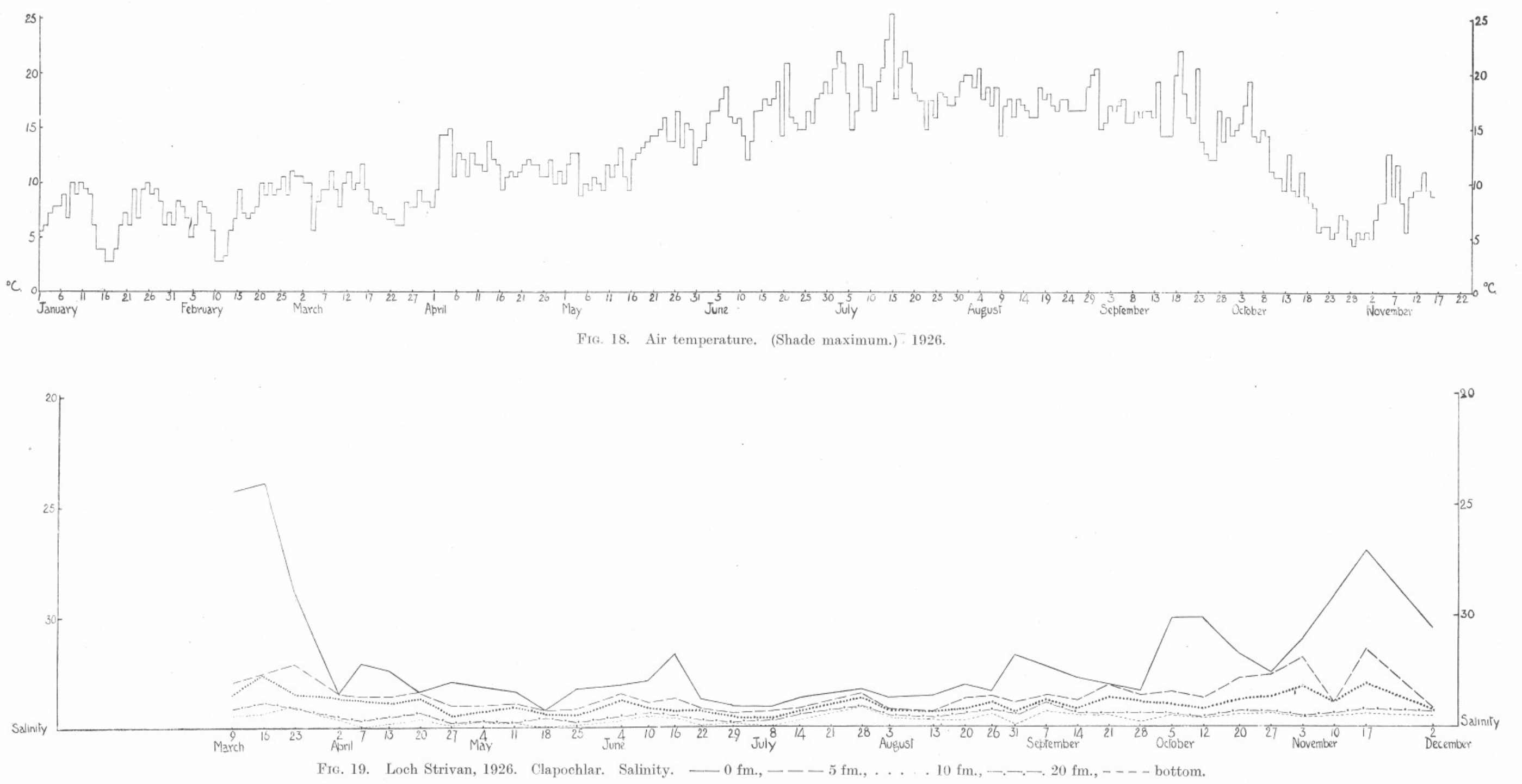